\title{
The protective immunity induced by SARS-CoV-2 infection and vaccination: a critical appraisal
}

\author{
Eduardo Tosta* (D) \\ Emeritus Professor, Faculty of Medicine, University of Brasília, Brasília 70757-100, Brazil
}

*Correspondence: Eduardo Tosta, SQN 311 Bloco J, Apto. 408, Faculty of Medicine, University of Brasília, Brasília 70757-100, Brazil. cetosta@unb.br

Academic Editor: Wangxue Chen, National Research Council Canada, Canada

Received: April 10, 2021 Accepted: June 24, 2021 Published: August 31, 2021

Cite this article: Tosta E. The protective immunity induced by SARS-CoV-2 infection and vaccination: a critical appraisal. Explor Immunol. 2021;1:199-225. https://doi.org/10.37349/ei.2021.00014

\begin{abstract}
Understanding the interactions of severe acute respiratory syndrome coronavirus-2 (SARS-CoV-2) with humans is deeply grounded in immunology, from the diagnosis to pathogenesis, from the clinical presentations to the epidemiology, prevention, and treatment. However, the difficulty of capturing the complex and changeable array of immunological concepts and incorporating them into the strategies of control of the SARS-CoV-2 pandemic poses significant hindrances to establish optimal public health policies. The contribution of immunology to the control of the pandemic is to shed light on the features and mechanisms of the protective immunity elicited by SARS-CoV-2 infection and vaccines. Do they induce effective protective immunity? How? For how long? What is the effect of vaccination on individuals who were previously infected? To appropriately answer these questions, it is necessary to get rid of the outdated notion of a naïve, static, and closed immune system, which leads to misconceptions about susceptibility, specificity, immunological memory, and protective immunity. The present essay discusses these issues based on current immunological concepts.
\end{abstract}

\section{Keywords}

Protective immunity, SARS-CoV-2 infection, SARS-CoV-2 vaccines, susceptibility, specificity, immunological memory, epitope selection, adaptation, permissive immunity

\section{Introduction}

The severe acute respiratory syndrome coronavirus-2 (SARS-CoV-2) infection has spread throughout the world at an astonishing rate, leading to overall sanitary, social, and economic disruption, and above all, causing an enormous burden of suffering and lost lives. Such a global threat calls for the global collaboration of all fields of human expertise. Immunology is but one of these fields, albeit quite a central one. Immunology provides insights into some of the core issues concerning why some infected subjects remain asymptomatic, while others develop a mild and self-limited disease, and a minority suffers a severe and lethal disease. 
Furthermore, the understanding of the pathogenesis of the disease and the rationale for its treatment, as well as the conceptual basis for the development of effective vaccines, are grounded on immunological knowledge.

However, the complexity and changeability of the immunological concepts make it difficult to be captured by the professionals involved in the control of SARS-CoV-2 infection. Consequently, some profoundly ingrained misconceptions hinder optimal control measures. For example, the assumption that, since SARS-CoV-2 is a novel human pathogen, the whole world population would be susceptible to the infection and, if no interventions were made, estimates of 7 billion infections and 40 million deaths would occur [1]. The supposition of universal susceptibility to novel pathogens is a misconception. Notwithstanding the novelty of the pathogen, a proportion of the exposed individuals always resist its infection. That happens due to the individual's natural resistance and the occurrence of cross-immunity induced by related or unrelated residents and environmental microorganisms [2,3]. At its first contact with the organism, the novel pathogen finds a fully functioning immune system composed of an array of cells capable of recognizing its components and reacting to them. Therefore, a pathogen never encounters an absolutely naïve immune system. Conversely, it is inserted into a highly dynamic setting of ongoing cellular and molecular interactions and provokes a perturbation of this network. Since the immune system is ruled by autopoiesis, it subsequently returns to a steady state, although at a different threshold. This flexibility allows it to cope with the pathogen while maintaining homeostasis. Another critical aspect of susceptibility is that it is not an all-or-nothing phenomenon but a continuum, which ranges from total susceptibility to complete resistance. It comprises a spectrum of intermediate states, which contributes to the different clinical presentations of the infection, spanning from asymptomatic to mild, moderate, severe, and fatal disease [4].

This essay discusses the features of protective immunity induced by SARS-CoV-2 infection and vaccination based on the current immunological concepts.

\section{The concepts of protective immunity, specificity, and immunological memory}

Protective immunity is an inclusive concept that implies some degree of advantage for the individual or the collectivity. At the individual level, it means the immune system's ability to resist infection or reinfection or attenuate an infectious disease or its clinical presentation. At the population level, it is known as herd or collective immunity and referred to as the indirect protection from infection, which is conferred to susceptible individuals when a sufficiently large proportion of immune individuals exist in a community [5].

The classical paradigm of immunology posits that protective immunity depends on two features of the adaptive immune system. The first is specificity, the ability of lymphocytes to discriminate self from nonself components and react to the latter [6,7]. The second is immunological memory, which refers to the long-lived specific lymphocytes' ability to promptly and efficiently respond to a reencounter with an immunogen $[8,9]$. However, these deep-rooted concepts were challenged by recent data, and currently, it has been established that some adaptive immune responses can display no specificity or memory, while some innate immune responses can exhibit both [10-15]. Furthermore, innate immune cells can be long-lived, and adaptive T and B lymphocytes can have innate features [16-18].

The concept of specificity has been significantly widened by demonstrating that the adaptive immune cells react, with different degrees of affinity, to the specific antigen and an array of other molecules, including environmental and resident microorganisms [19-21]. Indeed, the crucial role of the microbiome, virome, mycobiome, and probably, archaeome in the development, activation, and modulation of innate and adaptive immune systems have been recently acknowledged [22-25].

The classical paradigm of immunological memory posits that, at its first contact, the infectious agent (or the vaccine) finds an immune system populated by naïve lymphocytes, which had never been exposed to it before. The result of this encounter will be activation, proliferation, and differentiation of the cells into short-lived effector lymphocytes and long-lived memory lymphocytes. The latter would usually be kept in a quiescent state, waiting for the subsequent encounter with the same infectious agent (or vaccine), and would mediate more rapid, intense, and efficient responses. However, such a view involves two outdated conceptions. 
The first concerns the assumption of the immune system's naïvety, which some robust evidence has dismissed. The immune system is shaped, organized, activated, and modulated since the fetal life, initially by the microbiota, infectious antigens, immunoglobulins, and lymphocytes from maternal origin [26-29], and later by the myriad of constant antigenic stimuli, both from environmental and resident microorganisms, as well as from self-antigens [30-33]. Infectious agents contain several antigens, which are, in their turn, composed of a significant number of epitopes, each of them capable of inducing different immune responses, with different kinetics, dynamics, and outcomes, which may cross-react with those induced by several other infectious agents. Therefore, at its first contact, a pathogen neither finds a naïve and static immune system nor induces a single immune response that gives rise to effector and memory cells. Instead, it encounters a highly complex and dynamic immune system already formed and organized, with many immune responses in action, involving various cells at diverse activation and differentiation stages. These cells interact in different molecular landscapes under the effects of stimulatory and inhibitory signaling pathways, resulting in stimulation or inhibition of several immune responses. Immunological memory has to be understood within this context [16]. Recent findings show that effector CD8 T cells dedifferentiates into long-lived memory cells [34], and T memory cells possess a propensity to convert to another cell type by plasticity when active regulatory programs are lost $[35,36]$.

The second misconception of the classical paradigm of immunological memory is that it always enhances protective immunity. Infectious agents contain a great variety of epitopes capable of inducing different immune responses. The occurrence of protective immunity depends on the epitope's immunogenicity, its frequency, immunodominance, and relevance for the infectious agent and the type and interactions with reactive immune cells. For example, regulatory $\mathrm{T}$ memory cells are not expected to provide protective immunity as helper T memory cells $[9,37]$ or that enhancing-antibody producing B memory cells positively contributes to protection [38].

A frequent caveat on the interpretation of the phenomenon of immunological memory is taking the part for the whole when one infers that blood memory cells, the population usually studied, represent the entire repertoire of immunological memory cells. Memory cell repertoire includes a variety of phenotypically and functionally diverse populations of cells disposed of in different compartments, which comprise subsets of memory $\mathrm{T}$ lymphocytes (effector memory, central memory, tissue-resident memory, peripheral memory, and stem cell memory) [8,9] and memory B lymphocytes (T-cell dependent and independent memory, isotope-switched and unswitched, mutated and unmutated memory B cells, distributed as bone-marrow central memory and circulating long-lived plasma cells) [39, 40]. The memory cell pool is under constant transcriptional and epigenetic constraints by an array of antigenic stimuli, cellular interactions, cytokines and chemokines, hormones, neuropeptides, and several other factors [41-44]. It is, therefore, a very dynamic system subject to frequent changes that, in certain circumstances, may suffer cell apoptosis, leading to loss of memory [21]. Moreover, recent evidence shows that immunological memory extends beyond conventional B and T lymphocytes and includes natural killer (NK) cells and other innate lymphoid cells, as well as myeloid cells such as monocytes and macrophages [16]. These findings have widened the spectrum of immunological memory and added more difficulty to understanding how the memory repertoire is organized and functions.

Besides specificity and memory, protective immunity is influenced by the context in which the immune response occurs. It includes factors associated with the individual (genetic background, epigenetic makeup, age, hormonal and emotional influences, and the status of the immune system at the moment of the antigenic stimulation), factors depending on the antigenic stimulus as such (immunogenicity, antigenic load, interactions of the different immune responses induced by diverse epitopes), as well as on the virulence factors and escape mechanisms used by the infectious agent [45-50].

Finally, it has to be stressed that the detection of specific antibodies or lymphocytes that react to epitopes of an infectious agent is not a trustful indication of protective immunity. For example, it has been demonstrated that the synthesis of immunoglobulin (Ig)G antibodies to SARS-CoV-1 can persist from six years [51] to up to 12 years after infection [52], and T memory lymphocytes can be detected from six [53] up to 11 years post-infection [54]. However, these observations do not mean that protective immunity lasts for this time 
since antibodies and memory cells can be directed toward irrelevant components of the pathogen (e.g., those that do not imply a reduction of infectivity).

\section{Protective immunity induced by the SARS-CoV-2 infection}

The remarkable adaptability of SARS-CoV-2

To reach pulmonary cells and give rise to productive infection, SARS-CoV-2 has to overcome eight host defense barriers: mucus and mucociliary clearance, surfactant proteins, respiratory tract microbiota, the antimicrobial peptides defensins and lactoferrin, nonspecific secretory IgA antibodies, respiratory epithelial cell interferons, innate immunity, and adaptive immunity. For succeeding, the virus has developed strategies of survival that include impairment of interferon production; hiding immunogenic motifs; avoidance of viral RNA detection by cell sensors; triggering host cell death by apoptosis, necroptosis, or pyroptosis; induction of lymphocyte exhaustion and depletion; and virus mutation. Besides, SARS-CoV-2 uses strategies to take advantage of cell resources for its benefit by manipulating the process of autophagy, inhibiting the ubiquitin-proteasome system, and hijacking mitochondria functions.

Although destruction is the visible face of the relationship of SARS-CoV-2 with humans, it is not its aim. Destruction of the counterpart is harmful to both sides. If the virus destroys its host, it destroys itself, and if the host causes early elimination of the virus, immunity is not achieved. Therefore, immunity should be viewed as a strategy of adaptation, not destruction. Adaptation depends on tradeoffs between the pathogen and the host to improve mutual fitness and survival. Gene sequences of SARS-CoV-2 isolated from different geographic areas confirm that genetic changes of the virus are continuously arising, which ultimately promote adaptation $[55,56]$.

On the other hand, the virus constrains the host to produce hundreds to thousands of proteins involved in antiviral defense and virus replication and shedding [57]. These molecular changes are signatures of adaptation. Adaptation to the host is a frequent strategy of survival of infectious agents. Human coronaviruses NL63, HKU1, OC43, and 229E are now part of the human respiratory virome [58-61] and induce cross-reactive $\mathrm{T}$ [62-67] and B memory cells to SARS-CoV-2 [68-72].

\section{The role of antibodies in protective immunity}

It is well documented that SARS-CoV-2 infection induces potent immunity that is critical in clearing a primary infection. The protective immunity depends on the coordinated action of the three compartments of the adaptive immune system: B-cells, and CD4+ and CD8+ T cells [73]. Neutralizing antibodies have been considered as the correlate of protection in SARS-CoV-2 infection. They bind to the virus and directly block its ability to infect cells, usually by inhibiting the interaction between the viral spike (S) protein and the cellular angiotensin-converting enzyme-2 (ACE2) receptor. Several data demonstrate that most individuals infected with SARS-CoV-2 develop neutralizing antibodies that peak within 3-5 weeks of infection and decay afterwards [74-79], but keeping titers relatively stable for months [80] and increasing their avidity over time, an indication of underlying immune maturation [81]. The pattern of the initial rapid decay of neutralizing antibodies is due to the short half-life of the immunoglobulins and antibody-secreting cells. However, these cells are further replaced by a population of long-lived memory B cells $[82,83]$ that are remarkably stable and mature up to 6 months after SARS-CoV-2 infection and may provide long-lasting protection [69, 84]. Indeed, antibodies direct to SARS-CoV-2 S protein remain detectable for at least 11 months after infection due to the presence of long-lived bone marrow plasma cells [85].

Neutralizing antibody levels and kinetics vary with the clinical presentation of SARS-CoV-2 infection. Individuals with severe or moderate disease tend to have an earlier appearance of neutralizing antibodies at higher levels than those with mild illness [86-89]. Conversely, asymptomatic individuals frequently produce low levels or no neutralizing antibodies at all [86, 87]; paradoxically, the same pattern showed by those who die at early times post-onset of symptoms [89]. In addition, the higher neutralizing titers of moderate and severe subjects decrease following a two-phase pattern, with an initial rapid decline that significantly slows after day 80 [90]. 
An intriguing point about the protective effect of SARS-CoV-2 neutralizing antibodies is their positive correlation with the severity of clinical illness [87, 89, 91-98]. Different possibilities have been suggested for explaining this apparent paradox. It could be due to the higher viral loads of patients with severe SARS-CoV-2 infection $[89,99]$, to their more prolonged exposure to a greater abundance of viral antigens [94], or even to the phenomenon of antibody-dependent enhancement of the immune response [96]. Alternatively, the lower representation of regulatory $\mathrm{CD} 4+\mathrm{T}$ cells in patients with severe disease [100] could explain an excessive antibody production. This matter is still an open question.

Another category of antiviral antibodies bridges viral components to immune cells expressing Fc receptors (FcRs). They use different strategies to eliminate the virus: antibody-dependent cell-mediated cytotoxicity (ADCC) that is most commonly carried out by NK cells, and antibody-dependent endocytosis (ADEn), performed by macrophages, monocytes, and neutrophils. While NK cells involved in ADCC detect and destroy cells expressing virus components in their membrane, phagocytes involved in ADEn endocytose and destroy virus components complexed with IgG antibodies. Both Fc-dependent and neutralizing antibody functions are characterized and quantified by in vitro cell systems using plasma samples. Therefore, their biological importance in protective immunity is solely inferred.

Robust evidence shows that SARS-CoV-2 induces antibodies capable of engaging in ADCC or ADEn in most infected individuals, from asymptomatic to those with mild, moderate, or severe disease [101-105]. Fc-dependent antibody levels and functions are lower in asymptomatic individuals than those in symptomatic cases [105]. In mild to moderate patients, S-specific antibodies capable of Fc-mediated antiviral activity remain readily detectable in almost all donors up to four months post-infection, even in those whose neutralizing antibody responses have waned to undetectable levels [102]. By the second week of infection, those with severe disease presented higher levels of antibodies than those with moderate disease. Notably, while the individuals who survived severe disease successfully class-switched to IgG antibodies, with high-affinity FcR binding capacities, individuals who did not survive showed less robust switching and exhibited a delayed evolution of high-affinity FcR binding antibodies and Fc effector function [101].

Part of the long-lasting memory B cell pool is formed by pre-existing cross-reactive seasonal coronavirus-specific (HCoV-HKU1 and HCoV-OC43) clones, contributing to the early production of anti-SARS-CoV-2 neutralizing antibodies $[68,69,106]$. These cross-reacting antibodies are particularly prevalent in children and adolescents, are predominantly of the IgG class, and target the S2 subunit of the virus $\mathrm{S}$ protein, whereas SARS-CoV-2-induced neutralizing antibodies present in higher titers are either of the IgG, IgA, or IgM classes and target both S1 and S2 subunits [71]. Besides these findings, another point challenges the idea that SARS-CoV-2 primes only naïve cells at its first encounter with the immune system: the IgG antibodies' precocious appearance, sometimes preceding IgM antibodies during SARS-CoV-2 infection [107-109]. This pattern is compatible with a secondary immune response, suggesting a previous contact of the immune system with cross-reacting antigens. These facts are compelling and lead to the conclusion that, even at its first encounter with the immune system, a novel pathogen such as SARS-CoV-2 elicits various immune responses toward its diverse epitopes, some with features of secondary responses due to the occurrence of cross-reactivity with microorganisms from the microbiota and the external environment.

\section{The role of T lymphocytes in protective immunity}

Notwithstanding which effects antibodies may play in protective immunity to SARS-CoV-2, they can be overcome by other viral clearance mechanisms since mild infections can resolve before seroconversion [99, $110]$ or in its absence $[111,112]$. Moreover, $10-20 \%$ of symptomatically infected people have little or no detectable antibody $[113,114]$. And, more surprisingly, agammaglobulinemia patients, unable to produce antibodies, may present no symptoms or mild clinical manifestations when infected with SARS-CoV-2 and recover from the infection $[115,116]$. These observations point to the importance of the participation of $\mathrm{T}$ cells in the protective immunity to SARS-CoV-2 infection. Indeed, it has been shown that most of the convalescent subjects have undetectable antibodies but presented robust T-cell immunity against SARS-CoV-2 [117-119].

It is well established that $\mathrm{T}$ cells play a central role in protection against SARS-CoV-2 virus infection [120], and their early activation is associated with viral clearance and mild disease [121]. Different from neutralizing 
antibodies that peak within the first few weeks after the symptom onset and decay afterward, $\mathrm{T}$ cell responses to SARS-CoV-2 infection are generally more stable $[122,123]$. It has been shown that $100 \%$ of convalescent individuals present specific CD4+ T cells, while 70\% of them exhibit CD8+ T cells [64]. Interestingly, an association has been found between the proportion of CD8+ $\mathrm{T}$ cell responses and mild disease, suggesting a potential protective role of these cells [124]. In severe disease, CD4+ T cell responses are more frequent than those of CD8+ T cells [124], with increased proportions of cytotoxic follicular helper cells and cytotoxic $\mathrm{T}$ helper cells [100].

Antigen-specific CD4+ $\mathrm{T}$ cells expressing memory markers, as well as interleukin (IL)-2, interferon- $\gamma$ (IFN- $\gamma$ ), tumor necrosis factor (TNF), and CD154 (CD40 ligand), were markedly increased in COVID-19-recovered individuals compared with healthy donors $[63,64,125]$. However, the relative frequency of these cells decreased $22 \%$ to $32 \%$ six months after infection [126]. In addition, they overwhelmingly show a T helper (Th)1 pattern, considered a beneficial profile, as severe patients show reduced IFN- $\gamma$ and a shift to a more Th2 profile $[64,127]$. Although SARS-CoV-2-specific CD8+ T cells are also detected six months after infection, their responses are far more variable and generally less robust than those of CD4+ T cells [126].

A key yet unsettled aspect of the protective immunity to SARS-CoV-2 infection is the role of crossreactive T cells, found in $40 \%$ to $60 \%$ [64] to $100 \%[128,129]$ of the unexposed healthy individuals and that react to different virus proteins as $S$, membrane (M) [65, 118], and nucleocapsid (N) proteins [62]. Several research groups have identified the common cold coronavirus (HCoV-OC43, HCoV-HKU1, HCoV-NL63, and HCoV-229E), presenting different homology degrees with SARS-CoV-2, as responsible for the cross-reactivity with SARS-CoV-2 $[62,65,118,129,130]$. The common cold is the most frequent infectious disease in humans; adults have two to five episodes per year, and school children from seven to ten [131]. Human coronaviruses account for $8-15 \%$ of all cases [132].

The presence of cross-reactive $\mathrm{T}$ cells in a considerable fraction of the general population could explain the different COVID-19 clinical outcomes. In addition, it can affect the dynamics of the pandemic, impact the epidemiological models of herd immunity, and influence the design and performance of SARS-CoV-2 vaccines $[63,65]$. Furthermore, cross-reactive lymphocytes could help mount a faster, more robust, and persistent immune response upon exposure to SARS-CoV-2 and thereby limit disease severity $[67,128]$.

Real T-cell cross-reactivity implies that a single T-cell receptor recognizes more than one distinct peptide-major histocompatibility complex (MHC) ligand. That was demonstrated to occur in memory T-cells from SARS-CoV-2 infected individuals. Their receptors cross-react to epitopes of SARS-CoV-2 and seasonal human coronaviruses [133]. However, the low functional avidity of the cross-reactive TCRs for SARS-CoV-2 [128, 129, 133] makes them less susceptible to intrinsic negative control mechanisms [128] and argues against a significant role in infection [129]. Nevertheless, the finding that CD4+ cells isolated from unexposed healthy donors can differentiate towards the Th1 lineage in the presence of SARS-CoV- 2 proteins and produce IFN- $\gamma$ [130], a potent antiviral and immunomodulatory molecule, is highly suggestive of their functionality.

\section{The efficacy of post-infection immunity}

The question that emerged during the COVID-19 pandemic is whether the SARS-CoV-2 infection protects against reinfection and for how long. Eight months after the pandemic emerged, the first case of reinfection by a phylogenetically distinct variant of SARS-CoV-2 was reported [134] and was rapidly followed by many other cases worldwide [135]. While the known number of confirmed cases of reinfection represents a tiny fraction of the vast number of cases of COVID-19, it may nonetheless represent a small fraction of the persons who have been reinfected [136]. The more obvious reason for this unaccounted but undoubtedly significant sub-notification is that most individuals who became infected or reinfected did not have access to confirmatory laboratory tests or health services and were not included in the official datasets [137]. Furthermore, to characterize true reinfection and distinguish it from the recurrence of the initial infection, viral genome sequencing of virus samples collected in both situations has to be performed and compared [135, 137], which is not a trivial task. 
Notwithstanding those evident limitations and aware of the possibly tremendous number of unnotified cases, the risk of reinfection has been calculated in different settings. A study of 25,661 healthcare workers in England reported that a previous infection provides an 84\% risk reduction for reinfection, with a median protective effect observed seven months following primary infection. Notably, a variant of concern known as B.1.1.7 did circulate during the final part of the observation period, causing about $50 \%$ of all infections, but did not seem to affect reinfection rates [138]. Another investigation, comprising a cohort of 150,325 users of the United States health system that excluded healthcare workers, concluded that people previously infected by SARS-CoV-2 showed $78.5 \%$ protection and $83.1 \%$ against symptomatic infection [139]. Interestingly, the authors found that the protective effect increased over time, suggesting that the viral shedding or ongoing immune response may persist beyond 90 days and may not represent actual infection. The most extensive published study included a cohort of approximately 4 million Danish people and found that previous SARS-CoV-2 confers protection of $80.5 \%$, which decreased to $47.1 \%$ in those aged 65 years and older [140].

The variability of the features of reinfected people does not allow the definition of a clear pattern of those susceptible to reinfection. An analysis of 23 cases of reinfection found that the mean interval between the two episodes was 15 weeks; the mean age was 44.5 years; 56.5\% were male; in 17/23 (74\%), no comorbidity was observed in the first episode; in 10/23 (43.5\%), the second episode was milder, in 4 cases there was no difference in severity, in 7 cases the next episode was more severe, and in 2 cases both episodes were asymptomatic [141]. Another study encompassing 16 proved cases of reinfection showed that it occurred across demographic spectra; 8/16 (50\%) were between 20 and 30 years old, and in $75 \%$ of the cases, the initial infection was either asymptomatic or caused mild disease [135]. Reinfected people usually were not immunocompromised and, when tested, they present anti-SARS-CoV-2 antibodies [136].

Different possible explanations can be posed for explaining reinfection. The first is the waning of protective immunity induced by primo-infection since reinfections occurred after a mean interval of nearly four months when neutralizing antibodies, considered by some as correlates of protection, present low levels $[142,143]$. However, a study of 12,541 healthcare workers found that the presence of anti-S or anti-nucleocapsid IgG antibodies was associated with a substantially reduced risk of SARS-CoV-2 reinfection in the ensuing six months [144]. Another non-exclusive possibility is that reinfection was due to a new variant of the virus or an extremely high virus load, capable of escaping previous immunity. Detection of reinfection is most straightforward when the virus belongs to a different clade or lineage, as this provides clear evidence of infection by a different virus. Among 16 published reinfection cases, 5 (31\%) had a distinct clade or lineage detection between initial infection and reinfection, $8(50 \%)$ were infected with the same clade but had differences of $>2$ substitutions/month between them, and 3 cases (19\%) presented different D614G alleles [135].

The short time since SARS-CoV-2 emerged does not allow a definitive answer about the duration of the infection-induced protective immunity. However, the finding that infected individuals develop long-lived memory B cells $[82,83]$ that are remarkably stable and mature up to 6 months after SARS-CoV-2 infection [69, 84, 123], together with the demonstration of long-lived CD4+ and CD8+ memory T cells [63, 64, 123, 125], allows anticipating the occurrence of a somewhat lasting protective immunity. Still, it will likely reduce the frequency and severity of COVID-19 instead of leading to sterilizing immunity and prevention of reinfection.

\section{The antibody-dependent enhancement of the infection}

The finding that SARS-CoV-2 reinfection is sometimes more severe than the infection suggests the occurrence of antibody-dependent enhancement of infection (ADE). The ADE phenomenon facilitates virus entry into host cells and, consequently, enhances the infection [145]. The occurrence of ADE has been demonstrated in coronavirus infections, including middle-east respiratory syndrome coronavirus (MERS-CoV) [146], SARSCoV-1 $[147,148]$, and SARS-CoV-2 $[149,150]$. ADE ensues when antibodies binding to the virus particle fail to efficiently neutralize the virus, either because they bind to viral epitopes other than those involved in cell attachment and entry or due to the presence of sub-neutralizing concentrations of antibodies. The complex virus-antibody (IgG, IgM, or IgA), with or without complement (C), is internalized into those cells expressing Fc or $\mathrm{C}$ receptors, such as lymphocytes, monocytes, macrophages, dendritic cells, granulocytes, 
and endothelial cells. This process contributes to the augmentation of viral infection and the functional alteration of infected cells, ultimately exacerbating viral pathogenesis and disease severity $[151,152]$. The ability of SARS-CoVs to invade cells that do not express ACE2, but FC or C receptors, utilizing ADE has been demonstrated in vitro in human B cells, using sera from immunized animals, as well as from convalescent subjects [153], and in monocytes and macrophages, by using antibodies specific to the viral S protein [148, 154]. Active replication of SARS-CoVs in monocytes, macrophages, and lymphocytes has been demonstrated in vitro and in vivo, although not usually at a sustained higher level [155]. However, the virus's simple presence in the host cells' interior can alter cell function and viability [155-159], even in the absence of replication. ADE possibly plays a role in critical pathological mechanisms of SARS-CoV infection, such as lymphopenia, cytokine storm, and lung involvement $[38,156,157]$. The second peak of the throat and nasal virus load that occurs after the 9th day post-infection when antibodies to SARS-CoV-2 start to be detected [160], and the association between seroconversion and the worsening of the clinical conditions $[161,162]$ are highly suggestive of the occurrence of the ADE phenomenon.

\section{Protective immunity induced by SARS-CoV-2 vaccination}

Anti-SARS-CoV-2 vaccines were developed at an unprecedented speed and display an impressive efficacy in protecting from severe disease. However, several crucial questions remain under scrutiny. For example, 'what mechanisms of protective immunity do they induce, and how to measure them?'; 'how comparable is postvaccination immunity to post-infection immunity?'; 'what is the breadth of their effects on virus's genetic variants?'; and 'what is the duration of their effects?'

\section{What is vaccine efficacy?}

Many different endpoints are used in vaccine research to define efficacy. Outcome data from randomized controlled trials are often presented as a proportional reduction in disease between vaccinated and control participants to calculate the decline attributable to the vaccine. In the case of SARS-CoV-2, an efficacious vaccine might prevent infection, disease, or transmission. Alternatively, vaccines that do not affect the clinical course, but reduce the transmissibility of SARS-CoV-2, could still be valuable interventions on a population level [163]. Therefore, there are different vaccine 'efficacies', and the one so far attained by all SARS-CoV-2 vaccines is protection from severe disease and death in all settings, although the prevention of asymptomatic transmission and mild-to-moderate disease occurs less constantly [164].

\section{The features of SARS-CoV-2 vaccines}

By April 2021, there were over 200 SARS-CoV-2 vaccine candidates in various stages of preclinical and human testing, and five in phase IV trials: Pfizer/BioNTech + Fosun Pharma (BNT162b2); Moderna + National Institute of Allergic and Infectious diseases (mRNA-1273); AstraZeneca + University of Oxford (AZD1222); Sinovac Research and Development Co. (CoronaVac); and Janssen Pharmaceutical (Ad26.COV2.S), by Johnson and Johnson. These vaccines that have been deployed worldwide use three different formulations: mRNA that contains the sequence encoding pre-fusion S protein encapsulated in lipid nanoparticles (Pfizer/BioNTech and Moderna), DNA encoding S protein delivered by non-replicating adenovirus vectors (AstraZeneca and Jansen), and formaldehyde-inactivated virus (CoronaVac) $[165,166]$.

Each vaccine formulation uses different mechanisms for eliciting immune responses. For example, in RNA-based vaccines, the mRNA molecules captured by local innate immune cells are released from the lipid nanoparticles into the cytosol and sensed by toll-like-receptor (TLR) and retinoic acid-inducible gene (RIG)-I receptors. That elicits type I interferon secretion to the extracellular matrix, creating a milieu that favors Th1 responses over Th2. In the cytosol, mRNAs are directly translated by ribosomes into polypeptides processed by the proteasome system leading to peptide presentation onto MHC-I on the cell surface. Peptide presentation onto MHC-II may occur by antigen-presenting cells after uptake of extracellular proteins or cell debris containing protein [167]. This simplified model conveys several gaps that pose difficulties to understanding RNA-based SARS-CoV-2 vaccines. Since all cells express low-density lipoprotein receptors, the same used for capturing lipid nanoparticles [168], the consequences of the uptake of nanoparticles 
containing encapsulated mRNA by different local cells are unknown. After all, antigen-presenting cells are minimally represented among cells at the site of intramuscular injection. In this context, it has been shown that cells that have endocytosed mRNA in lipid nanoparticles secrete extracellular vesicles containing mRNA, which is possibly an alternative mechanism for delivering the molecules [167].

Notwithstanding how mRNA vaccines deliver the immunogen, protein production is detectable at the intramuscular injection site for up to ten days after vaccination [167]. Immunogen-laden dendritic cells further migrate to draining lymph nodes where interactions with $\mathrm{T}$ and $\mathrm{B}$ lymphocytes occur, leading to the formation of germinal centers and resulting in the generation of antibody-producing plasma cells and long-lived memory B cells. B-cells produce an array of epitope-specific antibodies with different functions, including neutralizing antibodies. These antibodies are usually in similar levels or higher than those found in sera of humans who recovered from infection and are lower in 65-85 years-old people [167]. After the first immunization with mRNA vaccines, neutralizing activity was detected in less than half of the subjects. However, all showed increased antibody titers and neutralization after the second immunization [169] and, when applied to previously SARS-CoV-2-infected individuals, can induce robust humoral and T-cell responses after a single dose [170-173], even when this happens one year after the infection [174]. Activated T cells are predominant of the CD4+ Th1 type and produce IFN- $\gamma$, TNF, and IL-2 cytokines when restimulated with SARSCoV-2 peptide pools [175], but CD8+ T cells are also induced [176].

The DNA vaccines delivered by non-replicating adenovirus vectors (AstraZeneca and Jansen) elicit effective immune responses and emulate the natural infection through the transgene products expressed. Vaccination of non-human primates with a DNA expressing different forms of SARS-CoV-2 S protein developed humoral and cellular immune responses, including neutralizing antibody titers at levels comparable to those found in convalescent humans and macaques infected with SARS-CoV-2 [177]. After vaccination, all animals were challenged with SARS-CoV-2. The vaccine encoding the full-length S protein resulted in $>3.1$ and $>3.7$ $\log 10$ reductions in median viral loads in bronchoalveolar lavage and nasal mucosa, respectively, compared with viral loads in sham controls [177].

The inactivated SARS-CoV-2 vaccines (e.g., CoronaVac) use the whole virus particles and, therefore, are supposed to elicit immune responses to all virus components. The vaccine triggers local activation of innate immune cells, production of type I interferons, activation of B cells that produce neutralizing antibodies, and CD8+ T cells with cytotoxicity to virus-infected cells [165].

\section{The quest for correlates of protection}

To date, all provisionally approved SARS-CoV-2 vaccines elicit humoral and cellular immune responses, including virus-specific binding antibodies, neutralizing antibodies, and virus-specific CD4+ and CD8+ T-cell responses. However, the measurement of vaccine efficacy is challenging, as efficacy trials need to include large cohorts to be followed for a long time. To circumvent that difficulty and allow comparisons between vaccines, correlates of protection ( $\mathrm{CoP}$ ) are used. An immune $\mathrm{CoP}$ is an immunological marker that reliably predicts protection against disease or infection after natural infection or vaccination [178]. The current unavailability of reliable CoPs [178-180] poses a significant hindrance in developing and deploying vaccines against SARS-CoV-2.

Neutralizing antibodies are sometimes considered as CoPs for assessing post-infection and post-vaccine protection due to the frequently positive correlation of their titers with the recovery from infection or efficacy of vaccines [181, 182]. However, this interpretation may be misleading. As previously discussed, SARS-CoV-2 infection and disease can be resolved without seroconversion, demonstrating that antibodies are not essential for recovery. Indeed, Th1 lymphocyte responses, cytotoxic lymphocytes, innate immune factors, trained immunity, and local mucosa immunity contribute to protection against SARS-CoV-2 infection and disease $[179,180,183]$. In addition, the antibody repertoire that participates in protective immunity probably includes those capable of mediating Fc-dependent functions as complement activation, phagocytosis, and antibody-dependent cellular cytotoxicity against SARS-CoV-2 [103, 184]. 
Moreover, convalescent plasma [185, 186] and monoclonal neutralizing antibodies [187, 188] have relatively limited effects on COVID-19 evolution. Finally, neutralizing antibodies comprise a heterogeneous array of antibodies of different isotypes, affinities, kinetics, functionality, and specificities [104, 105, 184, 189, 190] making it unrealistic to assign a single effect to them.

\section{The variants of concern}

The emergence of SARS-CoV-2 genetic variants of concern caused both surprise and concern. The surprise accounts for the unanticipated speed that variants of concern have arisen in a virus known for its slow mutation rate [191, 192], estimated from global phylogenies to accumulate approximately two mutations per month [164]. Within 28 days, from December 2020 to January 2021, three major variants of concern have emerged. The concern with the new variants arises from their potential to cause substantial additional mortality by affecting the efficacy of vaccination and disrupting the pandemic control programs [193]. Are these concerns justifiable?

Natural selection usually determines the fate of a newly arising mutation. However, other potential mechanisms such as chance events, host shifts, persistent infection in immunocompromised hosts, or mutations affecting the proofreading function could also drive viral evolution. Mutations confer a competitive advantage for viral replication, transmission, or escape from immunity. Therefore, mutated variants increase in frequency and become dominants [194]. By April 2021, three SARS-CoV-2 variants were considered of concern: B.1.1.7, B.1.351, and P.1. The B.1.1.7 variant (23 mutations with 17 amino acid changes) was first described in the United Kingdom on December 14, 2020; the B.1.351 variant (23 mutations with 17 amino acid changes) was initially reported in South Africa on December 18, 2020; and the P.1 variant (approximately 35 mutations with 17 amino acid changes) was reported in Brazil on January 12, 2021. By February 22, 2021, the B.1.1.7 variant had been reported in 93 countries, the B.1.351 in 45, and the P.1 in 21. All three variants have the N501Y mutation, which changes the amino acid asparagine $(\mathrm{N})$ to tyrosine $(\mathrm{Y})$ at position 501 in the receptor-binding domain (RBD) of the S protein. The B.1.351 and P.1 variants both have two additional RBD mutations, K417N/T and E484K. These mutations increase the binding affinity of RBD to the ACE2 SARS$\mathrm{CoV}-2$ receptor [195]. The major concerns stemming from the emergence of the new variants are their effects on viral transmissibility, disease severity, reinfection rates (i.e., escape from post-infection immunity), and vaccine effectiveness (i.e., escape from vaccine-induced immunity) [195].

Since its emergence, the B.1.1.7 variant largely replaced the circulating local lineages and became the predominant variant in the UK. This variant presents higher transmission, contributes to increased incidence, hospitalizations, and pressure on the health system [194]. Epidemiological studies and mathematical modeling suggest that it spreads $56 \%$ faster than other lineages and results in higher nasopharyngeal viral loads than the wild-type strain [194]. Retrospective observational studies estimate a $35 \%$ (12\% to 64\%) increased risk of death associated with the B.1.1.7 variant, indicating that it is not only more transmissible than pre-existing lineages, but can also cause more severe disease $[194,196]$. Plasma samples from vaccinated individuals show a modest reduction in the neutralization capacity toward the B.1.1.7 variant [197]. Sera from individuals vaccinated twice with the Pfizer-BioNTech BNT162b2 vaccine, longitudinally tested up to 6 weeks after vaccination, were able to neutralize the virus comparably to the D614G reference virus [198]. The AstraZeneca/Oxford AZD1222 vaccine showed efficacy against the B.1.1.7 variant, although sera from vaccinated individuals exhibited reduced neutralization activity [199].

One month after its detection, the B.1.351 variant had replaced the circulating viruses in the region and became the dominant variant, suggesting higher transmission rates. Similar to the B.1.1.7 variant, B.1.351 shares the N501Y mutation, located in the RBD of S protein, which confers an increased binding affinity of S RBD for the ACE2 receptor, raising the viral transmission rate. However, in addition to the N501Y mutation, this variant accumulates two additional mutations in the same RBD (K417N and E484K) that could play a pivotal role in the interaction with the receptor leading to immune evasion [194]. Indeed, the B.1.351 variant showed marked resistance to neutralization by convalescent plasma (9.4-fold) and sera from individuals who have received mRNA vaccines (10.3-12.4-fold) [200]. In addition, a clinical trial in South Africa evaluating a two-dose regime of the AstraZeneca/Oxford AZD1222 vaccine did not show protection against 
mild-to-moderate COVID-19 due to the B.1.351 variant [201]. However, the Novavax NVX-CoV2373 vaccine exhibited the expected response [202]. In addition, a mass vaccination campaign in Qatar showed that the Pfizer-BioNTech BNT162b2 mRNA vaccine presented approximately a $20 \%$ reduction efficacy associated with the B.1.351 variant [203]. No evidence of increased virulence or disease severity related to the B.1.351 variant has been reported [194].

The P.1 variant that was circulating in Manaus, Amazonas State, Brazil, in December 2020, soon became the dominant circulating virus in the country and later spread to 26 countries. It contains a unique constellation of lineage-defining mutations, including E484K, K417T, and N501Y [204], which are associated with increased affinity to ACE2 receptors [205], and resistance to neutralization by monoclonal antibodies [98, 206]. The P.1 variant caused a 2.6-fold increase of SARS-CoV-2 transmission and was considered the most transmissible among the variants of concern by April 2021 [207]. The possibility that CoronaVac protects against the P.1 variant has been suggested [208].

\section{Non-specific vaccines?}

The prevailing paradigm in vaccinology assumes that vaccines only protect against the target infection. However, epidemiological vaccine research has generated observations that contradict this assumption and suggest that vaccines have significant nonspecific effects on overall health in populations. These include the observations that several live vaccines reduce the incidence of all-cause mortality in vaccinated compared with unvaccinated populations far more than can be explained by protection against the target infections [209]. It is now established that several live-attenuated vaccines targeting infections like tuberculosis, measles, and polio induce protective innate immunity capable of affecting other pathogens [210]. Innate immune responses, triggered by a family of pattern recognition receptors, induce interferons and other cytokines and activate myeloid and lymphoid immune cells to provide protection against a wide range of pathogens [210]. Live-attenuated vaccines can induce a long-lasting and robust activation of innate immune cells by reprogramming their epigenetic makeup and thus endowing them with the capability to affect heterologous pathogens. Bacillus Calmette-Guérin (BCG) [211-213], measles, mumps, and rubella (MMR) vaccine [214] have been suggested to indirectly protect against SARS-CoV-2 infection by activating the innate immune system. Furthermore, a negative association was found between SARS-CoV-2 infection rates and previous vaccination with polio, Haemophilus influenzae type-B (HIB), MMR, varicella, pneumococcal conjugate (PCV13), Geriatric Flu, and hepatitis A/hepatitis B (HepA-HepB) vaccines [215].

\section{Protective immunity as an adaptive strategy}

The prevailing paradigm in immunology and vaccinology assumes that ideal protective immunity aims to keep the organism free of the target infectious agent. Hence, an effective immune response acts on some crucial components of the infectious agent to avoid the infection's success. However, this concept is now challenged by the proposal that protective immunity aims to facilitate the permanence of infectious agents in the organism with minimal harm and provide mutual adaptation. That means transforming pathogens into microbiota and, thus, promoting symbiosis ("living together") and coadaptation. Through this state of coadaptation, conditions are created for promoting coevolution [216, 217]. Therefore, the immune system acts to integrate microbes into the animal-cell community $[218,219]$. Amazingly, the individual's immune system is in part created by the own microbiota [220,221].

All living beings, from bacteria [222, 223] to plants [224] and animals [225], not only harbor infectious agents as they depend on them for living and evolution [226]. That means all living beings are holobionts [219]. Microbes of all kinds live around us, on us, within us, and even being a part of our DNA. Human cells are vastly outnumbered by microbial cells, and their symbiosis implies that millions of unique microbial genes work in conjunction with human genes. Humans' first exposure to microorganisms occurs during the fetal period through contact with the maternal microbiota [227]. Environmental viruses, bacteria, archaea, and fungi are selected to form the individual microbiota during and after birth. 
The human gut microbiota performs critical roles, including the biosynthesis of vitamins $\mathrm{K}$, biotin, folate; steroid hormones; and neurotransmitters (e.g., it is the major source of serotonin in the organism). It also metabolizes dietary components, short-chain fatty acids, drugs, and carcinogens; influences energy biogenesis, neurologic signaling, bone density, and vascularization; provides the immune system maturation, activation, and regulation [228, 229]; and critically promotes protection against pathogens [219].

Although the microbiome shows a degree of plasticity depending on the diet and host physiology, it exhibits remarkable stability, resilience, and diversity [230,231]. However, the more intriguing feature is its uniqueness [232, 233]. Each person's microbiota is so unique that its characterization is used as a forensic tool for identifying criminals [234]. That indicates that the selection of the microbiota's components is a genetically restricted process. As the only genetically restricted system in the organism is the immune system, the obvious conclusion is that the selection and maintenance of the microbiota depend on this system.

How does the immune system act permissibly rather than restrictively in the selection of the microbiota components? That involves mutual trade-offs between the microbe, the immune system, and target cells with gains and losses of each active part. These interactions are better understood with the gut microbiota, the largest and best known of the organism. It can be inhabited by some of the over 150,000 different identified species [235], together with a massive number of viruses, archaea, and fungi. These communities are coevolving with the immune cells over millions of years [236]. A central strategy of the immune system to maintain its homeostatic relationship with the microbiota is to minimize the contact between microorganisms and the epithelial cell surface, limit cell invasion and microbial translocation [25]. This segregation is partially achieved in the gastrointestinal tract by the epithelium, the mucus layer, antimicrobial peptides, and secretory IgA.

Segregation from the immune cells also interests the microbiota. To pursue that, microbiota bacteria produce molecules that promote the integrity and function of the intestinal epithelium, inhibit the production of proinflammatory cytokines, and induce the production of anti-inflammatory IL-10 [237, 238]. Furthermore, specific microbiota components promote Foxp3+ regulatory T (Treg) cell accumulation, supporting B cell class-switch and production of IgA [25]. Two kinds of secretory IgA are produced: T cell-independent (innate IgA) and T cell-dependent (adaptive IgA). While innate IgA can exclude microorganisms from the gut, those are not as potent as adaptive IgA in shaping a mutualistic relationship with the microbiota [239]. That happens because IgA molecules can coat microbiota bacteria and help them anchoring to the epithelial surface and, therefore, promoting colonization [240, 241].

On its part, the immune system plays a fundamental role in shaping and preserving the microbiota ecology, and both engage in a 'homeostatic dialogue' to reinforce each other's function [25]. Innate immune cells participate in this dialogue. Microbe-derived sphingolipids recognized by invariant natural killer T (iNKT) cells regulate their proinflammatory ability [242]. The adaptive immunity collaboration to the 'homeostatic dialogue' relies mainly on Treg cells. These cells regulate effector T-cell responses to gut bacteria, secrete anti-inflammatory and pro-tolerogenic cytokines such as IL-10 and transforming growth factor $\beta$ (TGF $\beta$ ) [243], and efficiently restrain aberrant type 2 or type 17 responses [244].

The microbiota is kept in the organism by the active and sustained action of the permissive immunity deployed by the immune system. Conversely, restrictive immunity is elicited when outside pathogens check homeostasis, which occurs in eventual circumstances. Over time, if the pathogen's contact continues, it may be incorporated into the microbiota through permissive immunity. It is important to keep in mind the velocity microbes adapt to new environments. Their growth rates usually vary between a few minutes to some hours. Thus, within 24 hours, they can give rise to several new microbe generations, speeding up adaptation.

A corollary of the concept that the primary goal of protective immunity is to eliminate pathogens from the organism is that the immune response is directed toward an antigen that is a crucial component of the pathogen. In SARS-CoV-2, this essential component is the S protein that the virus uses to enter host cells. Therefore, it is assumed that the protection against SARS-CoV-2 relies on neutralizing antibodies to $S$ protein to impede the virus' invasion. Most SARS-CoV-2 vaccines emulate this concept and use $S$ protein as their primary immunogen. Although the short-term results of vaccination are promising and show a 
reduction of the severe infection a few weeks after immunization [245], the long-term effects are unknown and may be disappointing. There are robust experimental data about SARS-CoV-2 epitopes, including their mapping [246], identification of those recognized by $T$ cells [247-250], and the immunoglobulin-binding epitopes [249, 251-253], the definition of epitope immunodominance and immunoprevalence [249, 250, 254], demonstration of their conformational dynamics [255], and detection of epitope mutations [251, 256]. Thus, it can be anticipated that the next generation of SARS-CoV-2 vaccines should contain a selection of multiple immunodominant epitopes from different virus structures and encompassing a maximum of known and predictable variants. It can also be anticipated that they will continue to follow the restrictive model of protective immunity. However, there would be very useful if the following vaccine formulations also contain epitopes capable of speeding up the trajectory of SARS-CoV-2 to become a component of the respiratory microbiota, as have already happened to other coronaviruses.

\section{Conclusions}

The difficulty of non-immunologists to capture the vast array of current immunological information and concepts and incorporate them into the strategies of controlling the SARS-CoV-2 pandemic represents significant hindrances for establishing realistic and reliable public health policies. Some misconceptions are so deeply rooted that they are hardly perceived, though their deleterious consequences are appreciable. The primary source of difficulty is the old notion of a naïve, static, and closed immune system. This idea assumes that, at its first contact, the infectious agent (or the vaccine) would find an immune system populated by naive lymphocytes, which have never been stimulated before. The results of this encounter would be activation, proliferation, and differentiation of the cells into short-lived effector lymphocytes and long-lived memory lymphocytes. The latter population would be kept in a quiescent state, waiting for the subsequent encounter with the infectious agent, when it would mediate a more rapid, intense, and efficient immune response. Robust experimental data surpassed this conception. Throughout life, since the fetal period, the immune system is maintained under continuous constraints induced by the antigens from environmental and resident microorganisms, self-antigens, and regulatory molecules from the nervous, endocrine, and immune systems. Therefore, the immune system must be considered an open system in constant communication with the external and internal environments. Such openness is responsible for the system's high dynamicity, whose cells are under continuous activation, differentiation, regulation, counter-regulation, and destruction. This current view of the immune system's organization and functioning, together with the erosion of the functional limits between adaptive and innate immune systems, has dramatically challenged the classical concepts of specificity, susceptibility, immunological memory, and protective immunity.

It is expected that the incorporation of the current concepts of immunology to the control of SARS-CoV-2 infection sheds light on some present misconceptions and contributes to reducing the burden of the COVID-19 pandemic.

\section{Abbreviations}

ACE2: angiotensin-converting enzyme-2

ADCC: antibody-dependent cell-mediated cytotoxicity

ADE: antibody-dependent enhancement

ADEn: antibody-dependent endocytosis

CoP: correlate of protection

COVID-19: coronavirus disease-19

IFN- $\gamma$ : interferon- $\gamma$

Ig: immunoglobulin

IL: interleukin

MHC: major histocompatibility complex 
mRNA: messenger RNA

NK: natural killer

RBD: receptor-binding domain

S: spike

SARS-CoV-2: severe acute respiratory syndrome coronavirus-2

Th: T helper

\section{Declarations}

Acknowledgments

I dedicate this work to my scientist colleagues worldwide who are giving their best to mitigating the tremendous suffering caused by SARS-CoV-2 infection in an unprecedentedly short time. I am grateful to Luzia Guimarães, Lena Tosta, Elza Dias-Tosta, and João Luiz Pacini for their helpful support.

\section{Author contributions}

As the sole author, I am responsible for the conception and preparation of the manuscript.

\section{Conflicts of interest}

The author declares that there are no conflicts of interest.

\section{Ethical approval}

Not applicable.

\section{Consent to participate}

Not applicable.

\section{Consent to publication}

Not applicable.

\section{Availability of data and materials}

Not applicable.

\section{Funding}

Not applicable.

\section{Copyright}

(c) The Author(s) 2021.

\section{References}

1. Walker PGT, Whittaker C, Watson OJ, Baguelin M, Ainslie KEC, Bhatia S, et al. The global impact of COVID-19 and strategies for mitigation and suppression. [Internet]. Imperial College, London; 2020 [cited 2021 January 21]. Available from: https://www.imperial.ac.uk/mrc-global-infectious-diseaseanalysis/covid-19/report-12-global-impact-covid-19/

2. Lee CH, Pinho MP, Buckley P, Woodhouse I, Ogg G, Simmons A, et al. CD8+ T cell cross-reactivity against SARS-CoV-2 conferred by other coronavirus strains and influenza virus. BioRxiv 107292 [Preprint]. 2020 [cited 2021 January 2]. Available from: https://www.biorxiv.org/ content/10.1101/2020.05.20.107292v1

3. Khan S, Nakajima R, Jain A, Assis RR, Jasinskas AI, Obiero JM, et al. Analysis of serologic cross-reactivity between common human coronaviruses and SARS-CoV-2 using coronavirus antigen microarray. 
BioRxiv 006544 [Preprint]. 2020 [cited 2021 January 21]. Available from: https://www.biorxiv.org/ content/10.1101/2020.03.24.006544v1

4. Tosta E. Transmission of severe acute respiratory syndrome coronavirus 2 through asymptomatic carriers and aerosols: a major public health challenge. Rev Soc Bras Med Trop. 2020;53:e20200669.

5. Randolph HE, Barreiro LB. Herd immunity: understanding COVID-19. Immunity. 2020;52:737-41.

6. Cohn M. A new concept of immune specificity emerges from a consideration of the self-nonself discrimination. Cell Immunol. 1997;181:103-8.

7. Langman RE. The specificity of immunological reactions. Mol Immunol. 2000;37:555-61.

8. Martin MD, Badovinac VP. Defining memory CD8 T cell. Front Immunol. 2018;9:2692.

9. Farber DL, Yudanin NA, Restifo NP. Human memory T cells: generation, compartmentalization and homeostasis. Nat Rev Immunol. 2014;14:24-35.

10. Netea MG, Joosten LAB, Latz E, Mills KHG, Natoli G, Stunnenberg HG, et al. Trained immunity: a program of innate immune memory in health and disease. Science. 2016;352:aaf1098.

11. Netea MG, Domínguez-Andrés J, Barreiro LB, Chavakis T, Divangahi M, Fuchs E, et al. Defining trained immunity and its role in health and disease. Nat Rev Immunol. 2020;20:375-88.

12. Muraille E, Goriely S. The nonspecific face of adaptive immunity. Curr Opin Immunol. 2017;48:38-43.

13. Holodick NE, Rodriguez-Zhurbenko N, Hernández AM. Defining natural antibodies. Front Immunol. 2017;8:872.

14. Cerwenka A, Lanier LL. Natural killer cell memory in infection, inflammation and cancer. Nat Rev Immunol. 2016;16:112-23.

15. Hammer Q, Romagnani C. About training and memory: NK-cell adaptation to viral infections. Adv Immunol. 2017;133:171-207.

16. Lau CM, Sun JC. The widening spectrum of immunological memory. Curr Opin Immunol. 2018;54:42-9.

17. Sun JC, Beilke JN, Lanier LL. Adaptive immune features of natural killer cells. Nature. 2009;457:557-61.

18. Yona S, Kim KW, Wolf Y, Mildner A, Varol D, Breker M, et al. Fate mapping reveals origins and dynamics of monocytes and tissue macrophages under homeostasis. Immunity. 2013;38:79-91.

19. Balz K, Trassl L, Härtel V, Nelson PP, Skevaki C. Virus-induced T cell-mediated heterologous immunity and vaccine development. Front Immunol. 2020;11:513.

20. Vojtek I, Buchy P, Doherty TM, Hoet B. Would immunization be the same without cross-reactivity? Vaccine. 2019; 37:539-49.

21. Welsh RM, Che JW, Brehm MA, Selin LK. Heterologous immunity between viruses. Immunol Rev. 2010;235:244-66.

22. Zheng D, Liwinski T, Elinav E. Interaction between microbiota and immunity in health and disease. Cell Res. 2020;30:492-506.

23. Chiu L, Bazin T, Truchetet ME, Schaeverbeke T, Delhaes L, Pradeu T. Protective microbiota: from localized to long-reaching co-immunity. Front Immunol. 2017;8:1678.

24. Belkaid Y, Hand TW. Role of the microbiota in immunity and inflammation. Cell. 2014;157:121-41.

25. Belkaid Y, Harrison OJ. Homeostatic immunity and the microbiota. Immunity. 2017;46:562-76.

26. Mcpherson AJ, Agüero MG, Ganal-Vonarburg SC. How nutrition and the maternal microbiota shape the neonatal immune system. Nat Rev Immunol. 2017;17:508-17.

27. Agüero MG, Ganal-Vonarburg SC, Fuhrer T, Rupp S, Uchimura Y, Li H, et al. The maternal microbiota drives early postnatal innate immune development. Science. 2016; 351:1296-302.

28. Jennewein MF, Abu-Raya B, Jiang Y, Alter G, Marchant A. Transfer of maternal immunity and programming of the newborn immune system. Sem Immunopathol. 2017;39:605-13. 
29. Zarnitsyna VI, Evavold BD, Schoettle LN, Blattman JN, Antia R. Estimating the diversity, completeness, and cross-reactivity of the T cell repertoire. Front Immunol. 2013;4:485.

30. Ganusov VV, Pilyugin SS, Ahmed R, Antia R. How does cross-reactive stimulation affect the longevity of CD8+ T cell memory? PloS Comput Biol. 2006;2:e55.

31. Takiishi T, Fenero CIM, Câmara NOS. Intestinal barrier and gut microbiota: shaping our immune responses throughout life. Tissue Barriers. 2017;5:e1373208.

32. Molloy M, Bouladoux N, Belkaid Y. Intestinal microbiota: shaping local and systemic immune responses. Semin Immunol. 2012;24:58-66.

33. Mayer A, Balasubramanian V, Walczak AM, Mora T. How a well-adapting immune system remembers. Proc Natl Acad Sci USA. 2019;116:8815-23.

34. Youngblood B, Hale JS, Kissick HT, Ahn E, Xu X, et al. Effector CD8 T cells dedifferentiate into long-lived memory cells. Nature. 2017;552:404-9.

35. Crotty S. Do memory CD4 T cells keep their cell-type programming: plasticity versus fate commitment? Complexities of interpretation due to the heterogeneity of memory CD4 T cells, including T follicular helper cells. Cold Spring Harb Perspect Biol. 2018;10:a032102.

36. Omilusik KD, Goldrath AW. Remembering to remember: T cell memory maintenance and plasticity. Curr Opin Immunol. 2019;58:89-97.

37. Rosenblum MD, Way SS, Abbas AK. Regulatory T cell memory. Nat Rev Immunol. 2016;16:90-101.

38. Wang Q, Zhang L, Kuwahara K, Li L, Liu Z, Li T, et al. Immunodominant SARS coronavirus epitopes in humans elicited both enhancing and neutralizing effects on infection in non-human primates. ACS Infect Dis. 2016;2:361-76.

39. Sanz I, Wei C, Lee FEH, Anolik J. Phenotypic and functional heterogeneity of human memory B cells. Semin Immunol. 2008;20:67-82.

40. Weisel F, Shlomchik M. Memory B cells of mice and humans. Annu Rev Immunol. 2017;35:255-84.

41. Surh CD, Sprent J. Homeostasis of naive and memory T cells. Immunity. 2008;29:848-62.

42. Jameson SC, Masopust D. Understanding subset diversity in T cell memory. Immunity. 2018;48:214-26.

43. Chen Y, Zander R, Khatun A, Schauder DM, Cui W. Transcriptional and epigenetic regulation of effector and memory CD8 T cell differentiation. Front Immunol. 2018;9:2826.

44. Tokoyoda K, Zehentmeier S, Hegazy AN, Albrecht I, Grün JR, Löhning M, et al. Professional memory CD4+ $\mathrm{T}$ lymphocytes preferentially reside and rest in the bone marrow. Immunity. 2009;30:721-30.

45. Huang Y, Dai H, Ke R. Principles of effective and robust innate immune response to viral infections: a multiplex network analysis. Front Immunol. 2019;10:1736.

46. Martins R, Carlos AR, Braza F, Thompson JA, Bastos-Amador P, Ramos S, et al. Disease tolerance as an inherent component of immunity. Annu Rev Immunol. 2019;37:405-37.

47. Soares MP, Teixeira L, Moita LF. Disease tolerance and immunity in host protection against infection. Nat Rev Immunol. 2017;17:83-96.

48. Zeng M, Nourishirazi E, Guinet E, Nouri-Shirazi M. The genetic background influences the cellular and humoral immune responses to vaccines. Clin Exp Immunol. 2016;186:190-204.

49. Taneja V. Sex hormones determine immune response. Front Immunol. 2018;9:1931.

50. Woodruff MC, Kim EH, Luo W, Pulendran B. B cell competition for restricted T cell help suppress rareepitope responses. Cell Rep. 2018;25:321-7.

51. Tang F, Quan Y, Xin ZT, Wrammert J, Ma MJ, Lv H, et al. Lack of peripheral memory B cell responses in recovered patients with severe acute respiratory syndrome: a six-year follow-up study. J Immunol. 2011;186:7264-8.

52. Guo X, Guo Z, Duan C, Chen Z, Wang G, Lu Y, et al. MedRxiv 20021386 [Preprint]. 2020 [cited 2021 January 22]. Available from: https://www.medrxiv.org/content/10.1101/2020.02.12.20021386v1 
53. Channappanavar R, Fett C, Zhao J, Meyerholz DK, Perlman S. Virus-specific memory CD8 T cells provide substantial protection from lethal severe acute respiratory syndrome coronavirus infection. J Virol. 2014;88:11034-44.

54. Ng OW, Chia A, Tan AT, Jadi RS, Leong HN, Berttoletti A, et al. Memory T cell responses targeting the SARS coronavirus persist up to 11 years post-infection. Vaccine. 2016;34:2008-14.

55. Yao H, Lu X, Chen Q, Xu K, Chen Y, Cheng L, et al. MedRxiv 20060160 [Preprint]. 2020 [cited 2021 January 22]. Available from: https://www.medrxiv.org/content/10.1101/2020.04.14.20060160v2

56. van Dorp L, Acman M, Richard D, Shaw LP, Ford CE, Ormond L, et al. Emergence of genomic diversity and recurrent mutations in SARS-CoV-2. Infect Genet Evol. 2020;83:104351.

57. Enard D, Cai L, Gwennap C, Petrov DA. Viruses are a dominant driver of protein adaptation in mammals. Elife. 2016;5:e12469.

58. Lysholm F, Wetterbom A, Lindau C, Darban H, Bjerkner A, Fahlander K, et al. Characterization of the viral microbiome in patients with severe lower respiratory tract infections, using metagenomic sequencing. PLoS One. 2012;7:e0875.

59. Thornburn F, Bennett S, Modha S, Murdoch D, Gunson R, Murcia PR. The use of next generation sequencing in the diagnosis and typing of respiratory infections. J Clin Virol. 2015;69:96-100.

60. Wang Y, Zhu N, Li Y, Lu R, Wang H, Liu G, et al. Metagenomic analysis of viral genetic diversity in respiratory samples from children with severe acute respiratory infection in China. Clin Microbiol Infect. 2016;22:458.

61. Graf EH, Simmon KE, Tardif KD. Hymas E, Flygare S, Eilbeck K, et al. Unbiased detection of respiratory viruses by use of RNA sequencing-based metagenomics: a systematic comparison to a commercial PCR Panel. J Clin Microbiol. 2016;54:1000-7.

62. Le Bert N, Tan AT, Kunasegaran K, Tham CYL, Hafezi M, Chia A, et al. SARS-CoV-2-specific T cell immunity in cases of COVID-19 and SARS, and uninfected controls. Nature. 2020;584:457-62.

63. Braun J, Loyal L, Frentsch M, Wendisch D, Georg P, Kurth F, et al. SARS-CoV-2-reactive T cells in healthy donors and patients with COVID-19. Nature. 2020;587:270-4.

64. Grifoni A, Weiskopf D, Ramirez SI, Mateus J, Dan JM, Moderbacher CR, et al. Targets of T cell responses to SARS-CoV-2 coronavirus in humans with COVID-19 disease and unexposed individuals. Cell. 2020;181:1489-501.

65. Mateus J, Grifoni A, Tarke A, Ramirez SI, Dan JM, Burger ZC, et al. Selective and cross-reactive SARS-CoV-2 T cell epitopes in unexposed humans. Science. 2020;370:89-94.

66. Qiu T, Mao T, Wang Y, Zhou M, Qiu J, Wang J, et al. Identification of potential cross-protective epitope between a new type of coronavirus (2019-nCoV) and severe acute respiratory syndrome virus. J Genet Genom. 2020;47:115-7.

67. Sette A, Crotty S. Pre-existing immunity to SARS-CoV-2: the knowns and unknowns. Nat Rev Immunol. 2020;20:457-8. Erratum in: Nat Rev Immunol. 2020;20:644.

68. Song G, He WT, Callaghan S, Anzanello F, Huang D, Ricketts J, et al. Cross-reactive serum and memory B-cell responses to spike protein in SARS-CoV-2 and endemic coronavirus infection. Nat Commun. 2021;12:2938.

69. Sokal A, Chappert P, Barba-Spaeth G, Roeser A, Fourati S, Azzaoui I, et al. Maturation and persistence of the anti-SARS-CoV-2 memory B cell response. Cell. 2021;184:1201-13.

70. Anderson EM, Goodwin EC, Verma A, Arevalo CP, Bolton MJ, Weirick ME, et al. Seasonal human coronavirus antibodies are boosted upon SARS-CoV-2 infection but not associated with protection. Cell. 2021;184:1858-64.

71. Ng KW, Faulkner N, Cornish GH, Rosa A, Harvey R, Hussain S, et al. Preexisting and de novo humoral immunity to SARS-CoV-2 in humans. Science. 2020;370:1339-43. 
72. Lim AI, Harrison OJ, Belkaid Y. Pre-birth memory. Nat Immunol. 2019;20:254-6.

73. Sette A, Crotty S. Adaptive immunity to SARS-CoV-2 and COVID-19. Cell. 2021;184:861-80.

74. Rodda LB, Netland J, Shehata L, Pruner KB, Morawski PA, Thouvenel CD, et al. Functional SARS- CoV-2specific immune memory persists after mild COVID-19. Cell. 2021;184:169-83.

75. Ibarrondo FJ, Fulcher JA, Goodman-Meza D, Elliott J, Hoffmann C, Hausner MA, et al. Rapid decay of antiSARS-CoV-2 antibodies in persons with mild Covid-19. N Engl J Med. 2020;383:1085-7.

76. Crawford KHD, Dingens AS, Eguia R, Wolf CR, Wilcox N, Logue JK, et al. Dynamics of neutralizing antibody titers in the months after SARS-CoV-2 infection. J Infect Dis. 2020;223:197-205.

77. Wu J, Liang B, Chen C, Wang H, Fang Y, Shen S, et al. SARS-CoV-2 infection induces sustained humoral immune responses in convalescent patients following symptomatic COVID-19. Nat Commun. 2021;12:1813.

78. Beaudoin- Bussières G, Laumaea A, Anand SP, Prévost J, Gasser R, Goyette G, et al. Decline of humoral responses against SARS-CoV-2 spike in convalescent individuals. mBio. 2020;11:e02590-20.

79. Marot S, Malet I, Leducq V, Zafilaza K, Sterlin D, Planas D, et al. Rapid decline of neutralizing antibodies against SARS-CoV-2 among infected healthcare workers. Nat Commun. 2021;12:844. Erratum in: Nat Commun. 2021;12:2824

80. Wajnberg A, Amanat F, Firpo A, Altman DR, Bailey MJ, Mansour M, et al. Robust neutralizing antibodies to SARS-CoV-2 infection persist for months. Science. 2020;370:1227-30.

81. den Hartog G, Vos ERA, den Hoogen LL, van Boven M, Schepp RM, Smits G, et al. Persistence of antibodies to SARS-CoV-2 in relation to symptoms in a nationwide prospective study. Clin Infect Dis. 2021; [Epub ahead of print].

82. Sakharkar M, Rappazzo CG, Wieland-Alter WF, Hsieh CL, Wrapp D, Esterman ES, et al. Prolonged evolution of the human B cell response to SARS-CoV-2 infection. Sci Immunol. 2021;6:eabg6916.

83. Hartley GE, Edwards ESJ, Aui PM, Varese N, Stojanovic S, McMahon J, et al. Rapid generation of durable B cell memory to SARS-CoV-2 spike and nucleocapsid proteins in COVID-19 and convalescence. Sci Immunol. 2020;5:eabf8891.

84. Abayasingam A, Balachandran H, Agapiou D, Hammoud M, Rodrigo C, Keoshkerian E, et al. Long-term persistence of $\mathrm{RBD}^{+}$memory B cells encoding neutralizing antibodies in SARS-CoV-2 infection. Cell Rep Med. 2021;2:100228.

85. Turner JS, Kim E, Kalaidina E, Goss CW, Rauseo AM, Schmitz AJ, et al. SARS-CoV-2 infection induces longlived bone marrow plasma cells in humans. Nature. 2021; [Epub ahead of print].

86. Jeewandara C, Jayathilaka D, Gomes L, Wijewickrama A, Narangoda E, Idampitiya D, et al. SARS-CoV-2 neutralizing antibodies in patients with varying severity of acute COVID-19 illness. Sci Rep. 2021;11:2062.

87. Chen X, Pan Z, Yue S, Yu F, Zhang J, Yang Y, et al. Disease severity dictates SARS-CoV-2-specific neutralizing antibody responses in COVID-19. Signal Transduct Target Ther. 2020;5:180.

88. Lau EHY, Tsang OTY, Hui DSC, Kwan MYW, Chan WH, Chiu SS, et al. Neutralizing antibody titres in SARSCoV-2 infections. Nat Commun. 2021;12:63.

89. Röltgen K, Powell AE, Wirz OF, Stevens BA, Hogan CA, Najeeb J, et al. Defining the features and duration of antibody responses to SARS-CoV-2 infection associated with disease severity and outcome. Sci Immunol. 2020;5:eabe0240.

90. Pradenas E, Trinité B, Urrea V, Marfil S, Ávila-Nieto C, Concepción MLR, et al. Stable neutralizing antibody levels 6 months after mild and severe COVID-19 episodes. Med. 2021;2:313-20.

91. Trinité B, Tarrés-Freixas F, Rodon J, Pradenas E, Urrea V, Marfil S, et al. SARS-CoV-2 infection elicits a rapid neutralizing antibody response that correlates with disease severity. Sci Rep. 2021;11:2608.

92. Schlickeiser S, Schwarz T, Steiner S, Wittke K, Al Besher N, Meyer O, et al. Disease severity, fever, age, and sex correlate with SARS-CoV-2 neutralizing antibody responses. Front Immunol. 2021;11:628971. 
93. Lynch KL, Whitman JD, Lacanienta NP, Beckerdite EW, Kastner SA, Shy BR, et al. Magnitude and kinetics of anti-severe acute respiratory syndrome coronavirus 2 antibody responses and their relationship to disease severity. Clin Infect Dis. 2021;72:301-8.

94. Wang K, Long QX, Deng HJ, Hu J, Gao QZ, Zhang GJ, et al. Longitudinal dynamics of the neutralizing antibody response to SARS-CoV-2 infection. Clin Infect Dis. 2021;73;e531-9.

95. Wang P, Liu L, Nair MS, Yin MT, Luo Y, Wang Q et al. SARS-CoV-2 neutralizing antibody responses are more robust in patients with severe disease. Emerg Microbes Infect. 2020;9:2091-3.

96. Chen W, Zhang J, Qin X, Wang W, Xu M, Wang LF, et al. SARS-CoV-2 neutralizing antibody levels are correlated with severity of COVID-19 pneumonia. Biomed Pharmacother. 2020;130:110629.

97. Hansen CB, Jarlhelt I, Pérez-Alós L, Landsky LH, Loftager M, Rosbjerg A, et al. SARS-CoV-2 antibody responses are correlated to disease severity in COVID-19 convalescent individuals. J Immunol. 2021;206:109-17.

98. Garcia-Beltran W, Lam EC, Astudillo MG, Yang D, Miller TE, Feldman J, et al. COVID-19-neutralizing antibodies predict disease severity and survival. Cell. 2021;184:476-88.

99. To KKW, Tsang OTY, Leung WS, Tam AR, Wu TC, Lung DC, et al. Temporal profiles of viral load in posterior oropharyngeal saliva samples and serum antibody responses during infection by SARS-CoV-2: an observational cohort study. Lancet Infect Dis. 2020;20:565-74.

100. Meckiff BJ, Ramírez-Suástegui C, Fajardo V, Chee SJ, Kusnadi A, Simon H, et al. Imbalance of regulatory and cytotoxic SARS-CoV-2-reactive CD4+ T cells in COVID-19. Cell. 2020;183:1340-53.

101. Zohar T, Loos C, Fischinger S, Atyeo C, Wang C, Slein MD, et al. Compromised humoral functional evolution tracks with SARS-CoV-2 mortality. Cell. 2020;18:1508-19.

102. Lee WS, Selva KJ, Davis SK, Wines BD, Reynaldi A, Esterbauer R, et al. Decay of Fc-dependent antibody functions after mild to moderate COVID-19. Cell Rep Med. 2021;2:100296.

103. Chen X, Rostad CA, Anderson LJ, Sun HY, Lapp SA, Stephens K, et al. The development and kinetics of functional antibody-dependent cell-mediated cytotoxicity (ADCC) to SARS-CoV-2 spike protein. Virology. 2021;559:1-9.

104. Atyeo C, Fischinger S, Zohar T, Slein MD, Burke J, Loos C, et al. Distinct early serological signatures track with SARS-CoV-2 survival. Immunity. 2020;53:524-32.

105. Dufloo J, Grzelak L, Staropoli I, Madec Y, Tondeur L, Anna F, et al. Asymptomatic and symptomatic SARSCoV-2 infections elicit polyfunctional antibodies. Cell Rep Med. 2021;2:100275.

106. Iyer AS, Jones FK, Nodoushani A, Kelly M, Slater D, Mills R, et al. Persistence and decay of human antibody responses to the receptor binding domain of SARS-CoV-2 spike protein in COVID-19 patients. Sci Immunol. 2020;5:eabe0367.

107. Li B, Li B, Feng F, Yang G, Liu A, Yang N, Jiang Q et al. Immunoglobulin G/M and cytokines detections in continuous sera from patients with novel coronaviruses (2019-nCoV) infection. Lancet Infect Dis 3543609 [Preprint]. 2020 [cited 2021 January 30]. Available from: https://ssrn.com/abstract=3543609

108. Du Z, Zhu F, Guo F, Yang B, Wang T. Detection of antibodies against SARS-CoV-2 in patients with COVID-19. J Med Virol. 2020;92:1735-38.

109. Suthar MS, Zimmerman MG, Kauffman RC, Mantus G, Linderman SL, Hudson WH, et al. Rapid generation of neutralizing antibody responses in COVID-19 patients. Cell Rep Med. 2020;1:100040.

110. Wölfel R, Corman VM, Guggemos W, Seilmaier M, Zange S, Müller MA, et al. Virological assessment of hospitalized patients with COVID-2019. Nature. 2020;581:465-9.

111. Wang B, Wang L, Kong X, Geng J, Xiao D, Ma C, et al. Long-term coexistence of SARS-CoV-2 with antibody response in COVID-19 patients. J Med Virol. 2020;92:1684-9.

112. Robbiani D, Gaebler C, Muecksch F, Lorenzi JCC, Wang Z, Cho A, et al. Convergent antibody responses to SARS-CoV-2 in convalescent individuals. Nature. 2020;584:437-42. 
113. Tan W, Lu Y, Zhang J, Wang J, Dan Y, Tan Z, et al. Viral kinetics and antibody responses in patients with COVID-19. MedRxiv 20042382 [Preprint]. 2020 [cited 2021 March 3]. Available from: https://www. medrxiv.org/content/10.1101/2020.03.24.20042382v1

114. Long QX, Tang XJ, Shi QL, Li Q, Deng HJ, Yuan J, et al. Clinical and immunological assessment of asymptomatic SARS-CoV-2 infections. Nat Med. 2020;26:1200-4.

115. Soresina A, Moratto D, Chiarini M, Paolillo C, Baresi G, Focà E, et al. Two X-linked agammaglobulinemia patients develop pneumonia as COVID-19 manifestation but recover. Pediatr Allergy Immunol. 2020;31:565-9.

116. Quinti I, Lougaris V, Milito C, Cinetto F, Pecoraro A, Mezzaroma I, et al. A possible role for B cells in COVID-19? Lesson from patients with agammaglobulinemia. J Allergy Clin Immunol. 2020;146:211-23.

117. Schwarzkopf S, Krawczyk A, Knop D, Klump H, Heinold A, Heinemann FM, et al. Cellular immunity in COVID-19 convalescents with PCR-confirmed infection but with undetectable SARS-CoV-2-specific IgG. Emerg Infect Dis. 2021; [Epub ahead of print].

118. Sekine T, Pérez-Potti A, Rivera-Ballesteros O, Strålin K, Gorin JB, Olsson A, et al. Robust T cell immunity in convalescent individuals with asymptomatic or mild COVID-19. Cell. 2020;18:158-68.

119. Altmann DM, Boyton RJ. SARS-CoV-2 T cell immunity: specificity, function, durability, and role in protection. Sci Immunol. 2020;5:eabd6160.

120. Moderbacher CR, Ramirez SI, Dan JM, Grifoni A, Hastie KM, Weiskopf D, et al. Antigen-specific adaptive immunity to SARS-CoV-2 in acute COVID-19 and associations with age and disease severity. Cell. 2020;18:996-1012.e19.

121. Tan AT, Linster M, Tan CW, Le Bert N, Chia WN, Kunasegaran K, et al. Early induction of functional SARSCoV-2-specific T cells associates with rapid viral clearance and mild disease in COVID-19 patients. Cell Rep. 2021;34:108728.

122. Zuo J, Dowell AC, Pearce H, Verma K, Long HM, Begum J, et al. Robust SARS-CoV-2-specific T cell immunity is maintained at 6 months following primary infection. Nature Immunol. 2021;22:620-6.

123. Dan JM, Mateus J, Kato Y, Hastie KM, Yu ED, Faliti CE, et al. Immunological memory to SARS-CoV-2 assessed for up to 8 months after infection. Science. 2021; 371:eabf4063.

124. Peng Y, Mentzer A, Liu G, Yao X, Yin Z, Dong D, et al. Broad and strong memory CD4 ${ }^{+}$and CD8 ${ }^{+} \mathrm{T}$ cells induced by SARS-CoV-2 in UK convalescent individuals following COVID-19. Nat Immunol. 2020;21:136-45.

125. Weiskopf D, Schmitz KS, Raadsen MP, Grifoni A, Okba NMA, Endeman H, et al. Phenotype and kinetics of SARS-CoV-2-specific T cells in COVID-19 patients with acute respiratory distress syndrome. Sci Immunol. 2020;5:eabd2071.

126. Breton G, Mendoza P, Hägglöf T, Oliveira TY, Schaefer-Babajew D, Gaebler C, et al. Persistent cellular immunity to SARS-CoV-2 infection. J Exp Med. 2021; 218:e20202515.

127. Oja AE, Saris A, Ghandour CA, Kragten NAM, Hogema BM, Nossent EJ, et al. Divergent SARS-CoV-2-specific T- and B-cell responses in severe but not mild COVID-19 patients. Eur J Immunol. 2020;50:1998-2012.

128. Bacher P, Rosati E, Esser D, Martini GR, Saggau C, Schiminsky E, et al. Pre-existing T cell memory as a risk factor for severe COVID-19 in the elderly. MedRxiv 20188896 [Preprint]. 2020 [cited 2021 March 10]. Available from: https://www.medrxiv.org/content/10.1101/2020.09.15.20188896v1

129. Bacher P, Rosati E, Esser D, Martini GR, Saggau C, Schiminsky E, et al. Low-avidity CD4+ $T$ cell responses to SARS-CoV-2 in unexposed individuals and humans with severe COVID-19. Immunity. 2020;5:1258-71.

130. Sałowska A, Karwaciak I, Karaś K, Dastych J, Ratajewski M. SARS-CoV-2 proteins induce IFNG in Th1 lymphocytes generated from CD4+ cells from healthy, unexposed Polish donors. Vaccines. 2020;8:673.

131. Johnston S, Holgate S. Epidemiology of viral respiratory infections. In: Myint S, Taylor-Robinson D, editors. Viral and other infections of the human respiratory tract. London: Chapman \& Hall; 1996. pp. 1-38. 
132. Gaunt ER, Hardie A, Claas ECJ, Simmonds P, Templeton KE. Epidemiology and clinical presentations of the four human coronaviruses 229E, HKU1, NL63, and OC43 detected over 3 years using a novel multiplex real-time PCR method. J Clin Microbiol. 2010;48:2940-7.

133. Dykema AG, Zhang B, Woldemeskel BA, Garliss CC, Cheung LS, Choudhury D, et al. Functional characterization of $\mathrm{CD}^{+} \mathrm{T}$ cell receptors cross-reactive for SARS-CoV-2 and endemic coronaviruses. J Clin Invest. 2021;131:e146922.

134. To KKW, Hung IFN, Ip JD, Chu AWH, Chan WM, Tam AR, et al. COVID-19 re-infection by a phylogenetically distinct severe acute respiratory syndrome coronavirus 2 strain confirmed by whole genome sequencing. Clin Infect Dis. 2020; [Epub ahead of print].

135. Babiker A, Marvil CE, Waggoner JJ, Collins MH, Piantadosi A. The importance and challenges of identifying SARS-CoV-2 reinfections. J Clin Microbiol. 2021;59:e02769-20.

136. Cohen JI, Burbelo PD. Reinfection with SARS-CoV-2: implications for vaccines. Clin Infect Dis. 2020; [Epub ahead of print].

137. Boyton RJ, Altmann DM. Risk of SARS-CoV-2 reinfection after natural infection. Lancet. 2021;397:1161-3.

138. Hall VJ, Foulkes S, Charlett A, Atti A, Monk EJM, Simmons R, et al. SARS-CoV-2 infection rates of antibody-positive compared with antibody-negative health-care workers in England: a large, multicentre, prospective cohort study (SIREN). Lancet. 2021;97:1459-69.

139. Sheehan MM, Reddy AJ, Rothberg MB. MedRxiv 21251715 [Preprint]. 2021 [cited 2021 March 21]. Available from: https://www.medrxiv.org/content/10.1101/2021.02.14.21251715v1

140. Hansen CH, Michlmayr D, Gubbels SM, Mølbak K, Ethelberg S. Assessment of protection against reinfection with SARS-CoV-2 among 4 million PCR-tested individuals in Denmark in 2020: a populationlevel observational study. Lancet. 2021;397:1204-12.

141. Roberts AT, Piani F, Longo B, Andreini R, Meini S. Reinfection of SARS-CoV-2 - analysis of 23 cases from the literature. Infect Dis. 2021; [Epub ahead of print].

142. Seow J, Graham C, Merrick B, Acors S, Pickering S, Steel KJA, et al. Longitudinal observation and decline of neutralizing antibody responses in the three months following SARS-CoV-2 infection in humans. Nature Microbiol. 2020;5:1598-607.

143. Chia WN, Ong SWX, Young BE, Fong SW, Le Bert N, Tan CW, et al. Dynamics of SARS-CoV-2 neutralising antibody responses and duration of immunity: a longitudinal study. Lancet Microbe. 2021;2:e240-49.

144. Lumley SF, O'Donnell D, Stoesser NE, Matthews PC, Howarth A, Hatch SB, et al. Antibody status and incidence of SARS-CoV-2 infection in health care workers. N Engl J Med. 2021;384:533-40.

145. Tirado SM, Yoon KJ. Antibody-dependent enhancement of virus infection and disease. Viral Immunol. 2003;16:69-86.

146. Wan Y, Shang J, Sun S, Tai W, Chen J, Geng Q et al. Molecular mechanism for antibody-dependent enhancement of coronavirus entry. J Virol. 2020;94:e02015-19.

147. Wang SF, Tseng SP, Yen CH, Yang JY, Tsao CH, Shen CW, etal. Antibody-dependentSARSCoronavirusinfection is mediated by antibodies against spike proteins. Biochem Biophys Res Commun. 2014;451:208-14.

148. Yip MS, Leung NHL, Cheung CY, Li PH, Lee HHY, Daëron M, et al. Antibody-dependent infection of human macrophages by severe acute respiratory syndrome coronavirus. Virol J. 2014;11:82.

149. Eroshenko N, Gill T, Keaveney MK, Church GM, Trevejo JM, Rajaniemi H. Implications of antibodydependent enhancement of infection for SARS-CoV-2 countermeasures. Nat Biotechnol. 2020;38:789-91.

150. Zhou Y, Liu Z, Li S, Xu W, Zhang Q, Silva IT, et al. Enhancement versus neutralization by SARS-CoV-2 antibodies from a convalescent donor associates with distinct epitopes on the RBD. Cell Rep. 2021;34:108699.

151. Kulkarni R. Antibody-dependent enhancement of viral infections. In: Bramhachari P, editor. Dynamics of immune activation in viral diseases. Singapore: Springer; 2020. pp. 9-41. 
152. Takada A, Kawaoka Y. Antibody-dependent enhancement of viral infection: molecular mechanisms and in vivo implications. Rev Med Virol. 2003;13:387-98.

153. Kam YW, Kien F, Roberts A, Cheung YC, Lamirande EW, et al. Antibodies against trimeric S glycoprotein protect hamsters against SARS CoV challenge despite their capacity to mediate Fc gamma RII-dependent entry into B cells in vitro. Vaccine. 2007;25:729-40.

154. Jaume M, Yip MS, Cheung CY, Leung HL, Li PH, Kien F, et al. Anti-severe acute respiratory syndrome coronavirus spike antibodies trigger infection of human immune cells via a $\mathrm{pH}$ - and cysteine proteaseindependent Fc $\gamma$ R pathway. J Virol. 2011;85:10582-97.

155. Yilla M, Harcourt BH, Hickman CJ, McGrew M, Tamin A, Goldsmith CS, et al. SARS-coronavirus replication in human peripheral monocytes/macrophages. Virus Res. 2005;107:93-101.

156. Chan PKS, Chen GG. Mechanisms of lymphocyte loss in SARS coronavirus infection. Hong Kong Med J. 2018;14 Suppl 4:S21-6.

157. Wang X, Xu W, Hu G, Xia S, Sun Z, Liu Z, et al. SARS-CoV-2 infects T lymphocytes through its spike proteinmediated membrane fusion. Cell Mol Immunol. 2020;7:1-3.

158. Li L, Wo J, Shao J, Zhu H, Wu N, Li M, et al. SARS-coronavirus replicates in mononuclear cells of peripheral blood (PBMCs) from SARS patients. J Clin Virol. 2003;28:239-44.

159. Nakagawa K, Lokugamage KG, Makino S. Viral and cellular mRNA translation in coronavirus-infected cells. Adv Virus Res. 2016;96:165-92.

160. Zou L, Ruan F, Huang M, Liang L, Huang H, Hong Z, et al. SARS-CoV-2 viral load in upper respiratory specimens of infected patients. N Engl J Med. 2020;382:1177-9.

161. Ho MS, Chen WJ, Chen HY, Lin SF, Wang MC, Di J, et al. Neutralizing antibody response and SARS severity. Emerg Infect Dis. 2005;11:1730-7.

162. Lee N, Chan PK, Ip M, Wong E, Ho J, Ho C, et al. Anti-SARS-CoV IgG response in relation to disease severity of severe acute respiratory syndrome. J Clin Virol. 2006;35:179-84.

163. Sherina N, Piralla A, Du L, Wan H, Kumagai-Braesch M, Andréll J, et al. Persistence of SARS-CoV-2specific $B$ and $T$ cell responses in convalescent COVID-19 patients 6-8 months after the infection. Med. 2021;2:281-95.

164. Hodgson SH, Mansatta K, Mallett G, Harris V, Emary KRW, Pollard AJ. What defines an efficacious COVID-19 vaccine? A review of the challenges assessing the clinical efficacy of vaccines against SARSCoV-2. Lancet Infect Dis. 2021;21:e26-35.

165. Gupta RK. Will SARS-CoV-2 variants of concern affect the promise of vaccines? Nat RevImmunol. 2021;21:340-1. Erratum in: Nat RevImmunol. 2021;21:405.

166. García-Montero C, Fraile-Martínez O, Bravo C, Torres-Carranza D, Sanchez-Trujillo L, Gómez-Lahoz AM, et al. An updated review of SARS-CoV-2 vaccines and the importance of effective vaccination programs in pandemic times. Vaccines. 2021;9:433.

167. McDonald I, Murray SM, Reynolds CJ, Altmann D, Boyton RL. Comparative systematic review and meta-analysis of reactogenicity, immunogenicity and efficacy of vaccines against SARS-CoV-2. NPJ Vaccines. 2021;6:74.

168. Cagigi A, Loré K. Immune responses induced by mRNA vaccination in mice, monkeys and humans. Vaccines. 2021;9:61.

169. Akinc A, Querbes W, De S, Qin J, Frank-Kamenetsky M, Jayaprakash KN, et al. Targeted delivery of RNAi therapeutics with endogenous and exogenous ligand-based mechanisms. Mol Ther. 2010;18:1357-64.

170. Jackson LA, Anderson EJ, Rouphael NG, Roberts PC, Makhene M, Coler RN, et al. An mRNA vaccine against SARS-CoV-2 - preliminary report. N Engl J Med. 2020;383:1920-31.

171. Prendecki M, Clarke C, Brown J, Cox A, Gleeson S, Guckian M, et al. Effect of previous SARS-CoV-2 infection on humoral and T-cell responses to single-dose BNT162b2 vaccine. Lancet. 2021;397:1178-81. 
172. Ebinger JE, Fert-Bober J, Printsev I, Wu M, Sun N, Prostko JC, et al. Antibody responses to the BNT162b2 mRNA vaccine in individuals previously infected with SARS-CoV-2. Nat Med. 2021;27:981-4.

173. Lustig Y, Nemet I, Kliker L, Zuckerman N, Yishai R, Alroy-Preis S, et al. Neutralizing response against variants after SARS-CoV-2 infection and one dose of BNT162b2. N Engl J Med. 2021;384:2453-4.

174. Manisty C, Otter AD, Treibel TA, McKnight A, Altmann DM, Brooks T. et al. Antibody response to first BNT162b2 dose in previously SARS-CoV-2-infected individuals. Lancet. 2021;397:1057-8.

175. Wang Z, Muecksch F, Schaefer-Babajew, Finkin S, Viant C, Gaebler C, et al. Naturally enhanced neutralizing breadth to SARS-CoV-2 after one year. BioRxiv 443175 [Preprint]. 2021 [cited 2021 April 3]. Available from: https://www.biorxiv.org/content/10.1101/2021.05.07.443175v2

176. Corbett KS, Edwards DK, Leist SR, Abiona OM, Boyoglu-Barnum S, Gillespie RA, et al. Vaccine design enabled by prototype pathogen preparedness. Nature. 2020;586:567-71.

177. Lu J, Lu G, Tan S, Xia J, Xiong H, Yu X, et al. A COVID-19 mRNA vaccine encoding SARS-CoV-2 virus-like particles induces a strong antiviral-like immune response in mice. Cell Res. 2020;30:936-9.

178. Yu J, Tostanovski LH, Peter L, Mercado NB, McMahan K, Mahrokian SH, et al. DNA vaccine protection against SARS-CoV-2 in rhesus macaques. Science. 2020;369:806-11.

179. Koch T, Mellinghoff SC, Shamsrizi P, Addo MM, Dahlke C. Correlates of vaccine-induced protection against SARS-CoV-2. Vaccines. 2021;9:238.

180. Sui Y, Bekele Y, Berzofsky JA. Potential SARS-CoV-2 immune correlates of protection in infection and vaccine immunization. Pathogens. 2021;10:138.

181. DiPiazza AT, Graham BS, Ruckwardt TJ. T cell immunity to SARS-CoV-2 following natural infection and vaccination. Biochem Biophys Res Commun. 2021;538:211-7.

182. Earle KA, Ambrosino DM, Fiore-Gartland A, Goldblatt D, Gilbert PB, Siber GR, et al. Evidence for antibody as a protective correlate for COVID-19 vaccines. Vaccine. 2021;39:4423-8.

183. Khoury DS, Cromer D, Reynaldi A, Schlub TE, Wheatley AK, Juno JA, et al. Neutralizing antibody levels are highly predictive of immune protection from symptomatic SARS-CoV-2 infection. Nat Med. 2021;27:1205-11

184. Juno JA, Tan HX, Lee WS, Reynaldi A, Kelly HG, Wragg K, et al. Humoral and circulating follicular helper T cell responses in recovered patients with COVID-19. Nat Med. 2020;26:1428-34.

185. Natarajan H, Crowley AR, Butler SE, Xu S, Weiner JA, Bloch EM, et al. SARS-CoV-2 antibody signatures robustly predict diverse antiviral functions relevant for convalescent plasma therapy. MedRxiv 20196154 [Preprint]. 2019 [cited 2021 April 3]. Available from: https://www.medrxiv.org/ content/10.1101/2020.09.16.20196154v1

186. Klein MN, Wang EW, Zimand P, Beauchamp H, Donis C, Ward MD, et al. Kinetics of SARS-CoV-2 antibody responses pre-COVID-19 and post-COVID-19 convalescent plasma transfusion in patients with severe respiratory failure: an observational case-control study. J Clin Pathol. 2021; [Epub ahead of print].

187. Sturek JM, Thomas TA, Gorham JD, Sheppard CA, Raymond AE, De Guex KP, et al. Convalescent plasma for preventing critical illness in COVID-19: a phase 2 trial and immune profile. MedRxiv 21251849 [Preprint]. 2021 [cited 2021 April 4]. Available from: https://www.medrxiv.org/ content/10.1101/2021.02.16.21251849v1

188. Weinreich DM, Sivapalasingam S, Norton T, Ali S, Gao H, Bhore R, et al. REGN-COV2, a neutralizing antibody cocktail, in outpatients with Covid-19. N Engl J Med. 2021;84:238-51.

189. Lundgren JD, Grund B, Barkauska CE, Holland TL, Gottlieb RL, Sandkovsky IJ, et al. A neutralizing monoclonal antibody for hospitalized patients with Covid-19. N Engl J Med. 2021;384:905-14.

190. Liu L, Wang P, Nair MS, Yu J, Rapp M, Wang Q, et al. Potent neutralizing antibodies against multiple epitopes on SARS-CoV-2 spike. Nature. 2020;584:450-6. 
191. Zohar T, Alter G. Dissecting antibody-mediated protection against SARS- CoV-2. Nat Rev Immunol. 2020;20:392-4.

192. Vilar S, Isom DG. One year of SARS-CoV-2: How much has the virus changed? Biology. 2021;10:91.

193. Dearlove B, Lewitus E, Bai H, Li Y, Reeves DB, Joyce MG, et al. A SARS-CoV-2 vaccine candidate would likely match all currently circulating variants. PNAS. 2020;117:23652-62.

194. Challen R, Brooks-Pollok E, Read JM, Dyson L, Tsaneneva-Atanasova K, Danon L. Risk of mortality in patients infected with SARS-CoV-2 variant of concern 202012/1: matched cohort study. BMJ. 2021;372:n579.

195. Gómez CE, Perdiguero B, Esteban M. Emerging SARS-CoV-2 variants and impact in global vaccination programs against SARS-CoV-2/COVID-19. Vaccines. 2021;9:243.

196. Karim SSA, Oliveira T. New SARS-CoV-2 variants - Clinical, public health, and vaccine implications. N Engl J Med. 2021;384:1866-8.

197. Horby P, Huntley C, Davies N, Edmunds J, Ferguson N, Medley G, et al. NERVTAG paper on COVID-19 variant of concern B.1.1.7. London: Crown copyright; 2021 [cited 2021 Jan 26].

198. Wibmer CK, Ayres F, Hermanus T, Madzivhandila M, Kgagudi P, Oosthuysen B, et al. SARS-CoV-2 501Y.V2 escapes neutralization by South African COVID-19 donor plasma. Nat Med. 2021;27:622-5.

199. Planas D, Bruel T, Grzelak L, Guivel-Benhassine F, Staropoli I, Porrot F, et al. Sensitivity of infectious SARS-CoV-2 B.1.1.7 and B.1.351 variants to neutralizing antibodies. Nat Med. 2021;27:917-24.

200. Emary KRW, Golubchik T, Aley PK, Ariani CV, Angus B, Bibi S, et al. Efficacy of ChAdOx1 nCoV-19 (AZD1222) vaccine against SARS-CoV-2 variant of concern 202012/01 (B.1.1.7): an exploratory analysis of a randomised controlled trial. Lancet. 2021;397:1351-62.

201. Wang P, Nair MS, Liu L, Iketani S, Luo Y, Guo Y, et al. Antibody resistance of SARS-CoV-2 variants B.1.351 and B.1.1.7. Nature. 2021;593:130-5.

202. Madhi SA, Baillie V, Cutland CL, Voysey M, Koen AL, Fairlie L, et al. Efficacy of the ChAdOx1 nCoV-19 Covid-19 vaccine against the B.1.351 variant. N Engl J Med. 2021;384:1885-98.

203. Shinde V, Bhikha S, Hoosain Z, Archary M, Bhorat Q, Fairlie L, et al. Efficacy of NVX-CoV2373 Covid-19 vaccine against the B.1.351 variant. N Engl J Med. 2021; 384:1899-909.

204. Abu-Raddad LJ, Chemaitelly H, Butt AA. Effectiveness of the BNT162b2 Covid-19 vaccine against the B.1.1.7 and B.1.351 variants. N Engl J Med. 2021;385:187-9.

205. Faria NR, Claro IM, Candido D, Franco LAM, Andrade PS, Coletti TM, et al. Genomic characterisation of an emergent SARS-CoV-2 lineage in Manaus: preliminary findings. Available from: https://virological.org/t/ genomic-characterisation-of-an-emergent-sarscov-2-lineage-in-manaus-preliminary-findings/586 (accessed on 9 May, 2021).

206. Dejnirattisai W, Zhou D, Supasa P, Liu C, Mentzer AJ, Ginn HM, et al. Antibody evasion by the P.1 strain of SARS-CoV-2. Cell. 2021;184:2939-54.

207. Wang Z, Schmidt F, Weisblum Y, Muecksch F, Barnes CO, Finkin S, et al. mRNA vaccine-elicited antibodies to SARS-CoV-2 and circulating variants. Nature. 2021;592:616-22.

208. Coutinho RM, Marquitti FMD, Ferreira LS, Borges ME, Silva RLP, Canton O, et al. Model-based estimation of transmissibility and reinfection of SARS-CoV-2 P.1 variant. MedRxiv 21252706 [Preprint]. 2021 [Cited 2021 April 4]. Available from: https://www.medrxiv.org/content/10.1101/2021.03.03.21252706v3

209. Hitchings MDT, Ranzani OT, Torres MSS, Oliveira SB, Almiron M, Said R, et al. Effectiveness of CoronaVac in the setting of high SARS-CoV-2 P.1 variant transmission in Brazil: a test-negative case-control study. MedRxiv 21255081[Preprint]. 2021[Cited 2021 April 4]. Available from: https://www.medrxiv.org/ content/10.1101/2021.04.07.21255081v4

210. Benn CS, Fisker AB, Rieckmann A,Sørup S, Aaby P. Vaccinology: time to change the paradigm? Lancet Infect Dis. 2020;20:e274-83. 
211. Chumakov K, Avidan MS, Benn CS, Bertozzi SM, Blatt L, Chang AY, et al. Old vaccines for new infections: exploiting innate immunity to control COVID-19 and prevent future pandemics. PNAS. 2021;118:e2101718118.

212. Yitbarek K, Abraham G, Girma T, Tilahun T, Woldie M. The effect of Bacillus Calmette-Guérin (BCG) vaccination in preventing severe infectious respiratory diseases other than TB: implications for the COVID-19 pandemic. Vaccine. 2020;38:6374-80.

213. Singh S, Maurya RP, Singh RK. "Trained immunity" from Mycobacterium spp. exposure or BCG vaccination and COVID-19 outcomes. PLoS Pathog. 2020;16:e1008969.

214. Berg MK, Yu Q Salvador CE, Melani I, Kitayama S. Mandated Bacillus Calmette-Guérin (BCG) vaccination predicts flattened curves for the spread of COVID-19. Sci Adv. 2020;eabc1463.

215. Ashford JW, Gold JE, Huenergardt MJA, Katz RBA, Strand SE, Bolanos J, et al. MMR vaccination: a potential strategy to reduce severity and mortality of COVID-19 illness. Am J Med. 2021;134:153-5.

216. Pawlowski C, Puranik A, Bandi H, Venkatakrishnan AJ, Agarwal V, Kennedy R, et al. Exploratory analysis of immunization records highlights decreased SARS-CoV-2 rates in individuals with recent non-COVID-19 vaccinations. Sci Rep. 2021;11:4741.

217. Tosta CE. Coevolutionary networks: a novel approach to understanding the relationships of humans with the infectious agents. Mem Inst Oswaldo Cruz. 2001;96:415-25.

218. Garrett WS, Gordon JI, Glimcher LH. Homeostasis and inflammation in the intestine. Cell. 2010; 140:859-70.

219. Gilbert SF, Sapp J, Tauber AI. A symbiotic view of life: we have never been individuals. Q Rev Biol. 2012;87:325-41.

220. Gilbert SF, Rosenberg E, Zilber-Rosenberg. The holobiont with its hologenome is a level of selection in evolution. In: Gissis SB, Lamm E, Shavit A, editors. Landscapes of collectivity in the life sciences. Cambridge: MIT Press; 2018. pp. 305-24.

221. Lanning DK, Rhee KJ, Knight KL. Intestinal bacteria and development of the B-lymphocyte repertoire. Trends Immunol. 2005;26:419-25.

222. Wesemann DR, Portuguese AJ, Meyers RM, Gallagher MP, Cluff-Jones K, Magee JM, et al. Microbial colonization influences early B-lineage development in the gut lamina propria. Nature. 2013;501:112-5.

223. Fortuna MA, Barbour MA, Zaman L, Hall AR, Buckling A, Bascompte J. Coevolutionary dynamics shape the structure of bacteria-phage infection networks. Evolution. 2019;73:1001-11.

224. Heilmann S, Sneppen K, Krishna S. Coexistence of phage and bacteria on the boundary of self-organized refuges. PNAS. 2012;109:12828-33.

225. Hawkes CV, Bull JJ, Lau JA. Symbiosis and stress: how plant microbiomes affect host evolution. Philos Trans R Soc Lond B Biol Sci. 2020;375:20190590.

226. Quercia S, Candela M, Giuliani C, Turroni S, Luiselli D, Rampelli S, et al. From lifetime to evolution: timescales of human gut microbiota adaptation. Front Microbiol. 2014;5:587.

227. Lederberg J. Infectious disease as an evolutionary paradigm. Emerg Infect Dis. 1997;3:417-23.

228. Younge N, McCann JR, Ballard J, Plunkett C, Akhtar S, Araújo-Pérez F, et al. Fetal exposure to the maternal microbiota in humans and mice. JCI Insight. 2019;4:e127806.

229. O'Hara AM, Shanahan F. The gut flora as a forgotten organ. EMBO Rep. 2006;7:688-93.

230. Faith JJ, Guruge JL, Charbonneau M, Subramanian S, Seedorf H, Goodman AL, et al. The long-term stability of the human gut microbiota. Science. 2013; 341:1237439.

231. Lozupone CA, Stombaugh JI, Gordon JI, Jansson JK, Knight R. Diversity, stability and resilience of the human gut microbiota. Nature. 2012;489:220-30.

232. Schloissnig S, Arumugam M, Sunagawa S, Mitreva M, Tap J, Zhu A, et al. Genomic variation landscape of the human gut microbiome. Nature. 2013;493:45-50. 
233. Knights D, Parfrey LW, Zaneveld J, Lozupone C, Knight R. Human-associated microbial signatures: examining their predictive value. Cell Host Microbe. 2011;10:292-6.

234. Robinson JM, Pasternak Z, Mason CE, Elhaik E. Forensic applications of microbiomics: a review. Front. Microbiol. 2021;11:608101.

235. Pasolli E, Asnicar F, Manara S, Zolfo M, Karcher N, Armanini F, et al. Extensive unexplored human microbiome diversity revealed by over 150,000 genomes from metagenomes spanning age, geography, and lifestyle. Cell. 2019;176:649-62.

236. Spencer SP, Fragiadakis GK, Sonnenburg JL. Pursuing human-relevant gut microbiota-immune interactions. Immunity. 2019;51:225-39.

237. Postler TS, Ghosh S. Understanding the holobiont: how microbial metabolites affect human health and shape the immune system. Cell Metabol. 2017;26:110-30.

238. McDermott AJ, Huffnagle GB. The microbiome and regulation of mucosal immunity. Immunology. 2013;142:24-31.

239. Sutherland DB, Suzuki K, Fagarasan S. Fostering of advanced mutualism with gut microbiota by Immunoglobulin A. Immunol Rev. 2016;270:20-31.

240. Weis AM, Round JL. Microbiota-antibody interactions that regulate gut homeostasis. Cell Host Microbe. 2021;29:34-46.

241. Huus KE, Petersen C, Finlay BB. Diversity and dynamism of IgA-microbiota interactions. Nat Rev Immunol. 2021;21:514-25.

242. An D, Oh SF, Olszak T, Neves JF, Avci FY, Erturk-Hasdemir D, et al. Sphingolipids from a symbiotic microbe regulate homeostasis of host intestinal natural killer T cells. Cell. 2014;156:123-3.

243. Russler-Germain EV, Rengarajan S, Hsieh CS. Antigen-specific regulatory T-cell responses to intestinal microbiota. Mucosal Immunol. 2017;10:1375-86.

244. Yang BH, Hagemann S, Mamareli P, Lauer U, Hoffman U, Beckstette M, et al. Foxp3(+) T cells expressing ROR $\gamma$ t represent a stable regulatory T-cell effector lineage with enhanced suppressive capacity during intestinal inflammation. Mucosal Immunol. 2016;9:444-57.

245. Chodick G, Tene L, Patalon T, Gazit S, Tov AB, Cohen D, et al. The effectiveness of the first dose of BNT162b2 vaccine in reducing SARS-CoV-2 infection 13-24 days after immunization: real-world evidence. MedRxiv 21250612 [Preprint]. 2021 [cited 2021 April 5]. Available from: https://www.medrxiv.org/ content/10.1101/2021.01.27.21250612v1

246. Dejnirattisai W, Zhou D, Ginn HM, Duyvesteyn HME, Supasa P, Case JB, et al. The antigenic anatomy of SARS-CoV-2 receptor binding domain. Cell. 2021;184:2183-200.

247. Grifoni A, Sidney J, Vita R, Peters B, Crotty S, Weiskopf D, et al. SARS-CoV-2 human t cell epitopes: adaptive immune response against COVID-19. Cell Host Microbe. 2021;29:1076-92.

248. Lee E, Sandgren K, Duette G, Stylianou VV, Khanna R, Eden JS, et al. Identification of SARS-CoV-2 nucleocapsid and spike T-cell epitopes for assessing T-cell immunity. J Virol. 2021;95:e02002-20.

249. Tarke A, Sidney J, Kidd CK, Dan JM, Ramirez SI, Yu ED, et al. Comprehensive analysis of T cell immunodominance and immunoprevalence of SARS-CoV-2 epitopes in COVID-19 cases. Cell Rep Med. 2021;2:100204.

250. Nguyen THO, Rowntree LC, Petersen J, Chua BY, Hensen L, Kedzierski L, et al. CD8 ${ }^{+}$T cells specific for an immunodominant SARSCoV-2 nucleocapsid epitope display high naïve precursor frequency and TCR promiscuity. Immunity. 2021;54:1066-82.

251. Voss WN, Hou YJ, Johnson NV, DelidakisG, Kim JE, Javanmardi K, et al. Prevalent, protective, and convergent IgG recognition of SARS-CoV-2 non-RBD spike epitopes. Science. 2021;372:1108-12.

252. Poh CM, Carissimo G, Wang B, Amrun SN, Lee CYP, Chee RSL, et al. Two linear epitopes on the SARS-CoV-2 spike protein that elicit neutralising antibodies in COVID-19 patients. Nat Commun. 2020;11:2806. 
253. Barnes CO, West, Jr. AP, Huey-Tubman KE, Hoffmann MAG, Sharaf NG, Hoffman PR, et al. Structures of human antibodies bound to SARS CoV-2 spike reveal common epitopes and recurrent features of antibodies. Cell. 2020;182:828-42.

254. Saini SK, Hersby DS, Tamhane T, Povlsen HR, Hernandez SPA, Nielsen M, et al. SARS-CoV-2 genome-wide $\mathrm{T}$ cell epitope mapping reveals immunodominance and substantial CD8 ${ }^{+} \mathrm{T}$ cell activation in COVID-19 patients. Sci Immunol. 2021;6:eabf7550.

255. Lu M, Uchil PD, Li W, Zheng D, Terry DS, Gorman J, et al. Real-time conformational dynamics of SARS-CoV-2 spikes on virus particles. Cell Host Microbe. 2020;28:880-91.

256. Agerer B, Koblischke M, Gudipati V, Montaño-Gutierrez LF, Smyth M, Popa A, et al. SARS-CoV-2 mutations in MHC-I-restricted epitopes evade CD8 ${ }^{+}$T cell responses. Sci Immunol. 2021;6:eabg6461. 